\title{
Next generation taxonomy: integrating traditional species description with the holobiont concept and genomic approaches - The in-depth characterization of a novel Euplotes species as a case study
}

\author{
Valentina Serra $^{1^{*}}$, Leandro Gammuto ${ }^{{ }^{*}}$, Venkatamahesh Nitla $^{1}$, Michele Castelli ${ }^{2}$, Olivia \\ Lanzoni $^{1}$, Davide Sassera ${ }^{3}$, Claudio Bandi ${ }^{2}$, Bhagavatula Venkata Sandeep ${ }^{4}$, Franco Verni ${ }^{1}$, \\ Letizia Modeo $^{1 \#}$, Giulio Petroni" ${ }^{1 \#}$
}

${ }^{1}$ Department of Biology, University of Pisa, Pisa, Italy;

${ }^{2}$ Romeo and Enrica Invernizzi Pediatric Research Center, Department of Biosciences, University of Milan, Milan, Italy;

${ }^{3}$ Department of Biology and Biotechnology “Lazzaro Spallanzani”, Pavia University, Pavia, Italy;

${ }^{4}$ Department of Biotechnology Andhra University, Visakhapatnam, India.

*Authors who contributed equally to this work.

\# Corresponding authors

\begin{abstract}
In 1991 Margulis defined holobionts as the assemblage of "two or more organisms, members of different species" which remain associate "throughout a significant portion of the life history". In recent times, holobionts have been described among many and far-related groups of living beings, such as plants, algae, insects, corals, and even humans. These studies have arisen an increasing interest in different contexts but, to our knowledge, the holobiont concept has not been applied in taxonomy. Here we propose a new approach to modern taxonomy, aimed to integrate the holobiont concept and genomic and bioinformatic analyses with the classical/morphological tools traditionally used in taxonomy. The inclusion of symbiont morphology, and of mitochondrial and symbiont genomes will allow the discipline to move toward what could become the "next generation taxonomy". As an example of this new paradigm in the characterization of holobionts, we herein provide the taxonomic description of the ciliate protist Euplotes vanleeuwenhoeki sp. nov. (Euplotia, Ciliophora) and its bacterial endosymbiont "Candidatus Pinguicoccus supinus" gen. nov., sp. nov. (Opitutae, Verrucomicrobia). Interestingly, we found that this endosymbiont has an extremely reduced genome ( $163 \mathrm{Kbp})$, which is suggestive of a high integration with the host and represents the first case of such an extreme reduction in Verrucomicrobia, and the first case in a protist host.
\end{abstract}


bioRxiv preprint doi: https://doi.org/10.1101/666461; this version posted June 11,2019 . The copyright holder for this preprint (which was not certified by peer review) is the author/funder, who has granted bioRxiv a license to display the preprint in perpetuity. It is made available under aCC-BY-NC-ND 4.0 International license.

\section{Introduction}

Starting from the de Bary's definition of symbiosis ("the living together of two differently named organisms" - de Bary 1879), Lynn Margulis defined the term "holobiont" (Meyer-Abich 1950) as the assemblage of "two or more organisms, members of different species" (bionts), which remain associate "throughout a significant portion of the life history" (Margulis 1991). Thus, a holobiont was defined as a compound of different species that together form a single ecological unit. In recent times, an increasing interest regarding holobionts has arisen, leading to different interpretations of the concept (Rosenberg et al. 2007; Zilber-Rosenberg and Rosenberg 2008) and to different theories on the underlying evolutionary driving forces (Rosenberg et al. 2007, 2009; Zilber-Rosenberg and Rosenberg 2008; Rosenberg and Zilber-Rosenberg 2011; Bordenstein and Theis 2015; Bosch and Miller 2016; Roughgarden et al. 2018). Nevertheless, the subject is still debated, especially regarding the applicability of the "holobiont" definition and the evolutionary implications of the concept and, in particular, on the 'boundaries' of the holobiont, intended as which associations should be considered within this definition. The visions span from the Mindell definition of highly integrated bionts sharing evolutionary paths, which we could view as 'holobiont sensu stricto', to the broadest sense, thus including even transient members of the microbiome (Mindell 1992, Casiraghi 2012; Moran and Sloan 2015; Douglas and Werren 2016; Hester et al. 2016; Queller and Strassmann 2016; Skilling 2016).

Holobionts have been described among many and far-related groups of living beings, such as plants (for review see: Vandenkoornhuyse et al. 2015; Sanchez-Canizares et al. 2017), algae (Egan et al. 2012), insects (for review see: Guerrero et al. 2013; Minard et al. 2013; Berlanga and Guerrero 2016), corals (Vezzulli et al. 2013; for review see: Thompson et al. 2015; van de Water et al. 2018), and even humans (Postler and Ghosh 2017). In this landscape, protists are under-represented, even though they are highly diverse and environmentally widespread (Šlapeta et al. 2005; Foissner 2006; Weisse 2008), and known for their association with a wide range of other microorganisms (Molmeret et al. 2005; Horn 2008; Ohkuma 2008; Schmitz-Esser et al. 2010; for review see: Gast et al. 2009; Görtz 2010; Nowack and Melkonian 2010; Schweikert et al. 2013; Scheid 2014).

In our opinion the holobiont concept could be very useful for the description of living beings, introducing a new parameter for their taxonomic description, i.e. the presence of stably associated organisms. Indeed, the presence of these organisms can influence the host, its physiology, and its adaptability to the environment (e.g. Rosati et al. 1999, Grosser et al., 2018, Bella et al., 2016); moreover, in some cases it has been shown to influence also its morphology (Giambelluca and Rosati 1996), the fundamental parameter of traditional taxonomy. The introduction of this novel point of view could contribute in rejuvenating the current state of taxonomy (i.e. the science of defining and naming groups of biological organisms based on shared characteristics and, more recently, based on evolutionary relationships).

Classical taxonomy was exclusively based on morphological-comparative techniques requiring a very high specialization on specific taxa. For this reason, and due to the development and rise of modern molecular tools, in the last decades this discipline has faced a significant period of crisis (Mallet and Willmott 2003; Agnarsson and Kuntner 2007). Lately, traditional taxonomy has been renewed in the so-called integrative taxonomy, which also includes ultrastructural and phylogenetic-molecular analysis (Mallet and Willmott 2003; Walter and Winterton 2007). 
bioRxiv preprint doi: https://doi.org/10.1101/666461; this version posted June 11, 2019. The copyright holder for this preprint (which was not certified by peer review) is the author/funder, who has granted bioRxiv a license to display the preprint in perpetuity. It is made available under aCC-BY-NC-ND 4.0 International license.

Now, in our opinion, it is time for another step forward: the future of taxonomic sciences needs to consider and take advantage from the holobiont concept, pursuing a further multidisciplinary integration with modern available technologies, such as bioinformatics and genomic analyses.

We believe that the holobiont concept can be a useful and innovative way to describe a living system in all its components, using a multidisciplinary approach that could further enrich the present integrative taxonomy.

Indeed, although at the moment not mandatory for the description of an organism, the characterization of obligatory or occasional symbionts, sensu de Bary (1879) as well as associated microbial consortium (=microbiome), can be considered as an additional useful descriptor of the state of an organism, potentially influencing its development, physiology, and morphology, as observed in previous studies (McFall-Ngai, 2002; Gilbert et al., 2010, 2015; Pradeu, 2011).

As mentioned above, nowadays, the term holobiont is ambiguously defined, indeed it can span from including only obligate mutualistic symbionts to somehow associated microbial consortia. In our opinion, it would be appropriate to apply the concept of holobiont each time the association between different organisms leads to the creation of a functional unit in which emerging characteristics and properties are not typical of the different parts taken separately. In this context, any symbiosis, mutualistic, neutral, or parasitic, affecting either morphology, physiology, or fitness of the host, would be framed.

Such a novel approach implies the necessity to describe each organism of the holobiont and, therefore, the need to build networks of complementary skills, able to combine bio-taxonomy tools, classical morphology, ultrastructure, molecular phylogeny, genomics, and bioinformatics. The proposed framework has the potential to represent a conceptual and methodological advance in taxonomy. Therefore, we propose to define this updated approach as "next generation taxonomy".

To exemplify the power of this new taxonomic approach for the characterization of holobionts, we herein present the taxonomic description of the ciliate protist Euplotes vanleeuwenhoeki sp. nov. (Euplotia, Ciliophora) and its bacterial endosymbiont "Candidatus $(\mathrm{Ca}$.) Pinguicoccus supinus" gen. nov., sp. nov. (Opitutae, Verrucomicrobia). Ciliates are known to form stable associations with eukaryotic (Graham and Graham 1980; Finlay et al. 1987; Kodama and Fujishima 2012; Fokin et al. 2014; Lanzoni et al. 2016; He et al. 2019) and prokaryotic (Rosati et al. 1999; van Hoek et al. 2000; Ferrantini et al. 2009; Modeo et al. 2013a, b; Gong et al. 2014; Serra et al. 2016; Szokoli et al. 2016; Castelli et al. 2019; Fokin et al. 2019) organisms, and thus represent an ideal case of study for the proposed "next generation taxonomy". Moreover, to the best of our knowledge, this is the first study addressing the concept of holobionts of protists in general.

In detail, we used the proposed approach combining the requirements of an integrative taxonomic description (Warren et al., 2017), and some novel analyses, such as the host mitochondrial genome characterization, with the genomic study on the endosymbiont. Interestingly, we found that the endosymbiont " $\mathrm{Ca}$. Pinguicoccus supinus" has an extremely small genome ( $163 \mathrm{kbp})$, comparable in size to extremely reduced genomes of insect symbionts, making this bacterium the first of this category found in a unicellular host (McCutcheon and Moran 2012; Bennett et al. 2016). The extremely small genome size is suggestive of a high level of integration with the host, further indicating the appropriateness of the use of a unifying holobiont/hologenomic approach to ensure a 
suitable functional and taxonomical description of all the partners involved in such kind of symbioses.

\section{Material and Methods}

\section{Sample collection and cell culturing}

The strain KKR18_Esm was collected on August $8^{\text {th }} 2014$, in one emissary of the freshwater Lake of Kolleru (16³6' 05.0"N, E081 18 47.8). Kolleru Lake is the largest freshwater body of India, and a protected Ramsar area due to seasonal migratory birds. It is situated between the deltas of two major rivers, Godavari and Krishna, $15 \mathrm{~km}$ south-east from the city of Eluru, in Andhra Pradesh state. The depth of Kolleru Lake is usually around $150-300 \mathrm{~cm}$, but at the time of sampling, the lake was almost dried up and the water level had dropped to the depth of 60-90 cm. Samples were collected at a depth of $15-30 \mathrm{~cm}$ near the shore of the lake using sterile $50 \mathrm{ml}$ Falcon tubes: both water and sediment were collected at once.

The original sample was screened by pouring about $20 \mathrm{ml}$ of water in a Petri dish. Single cells were collected using a micropipette, washed several times in mineral water, put in a depression slide and enriched with a few drops of the monoclonal culture of Dunaliella tertiolecta (original salinity 5\%, diluted to freshwater) as food to obtain monoclonal cultures. These were maintained in incubator at a temperature of $19 \pm 1{ }^{\circ} \mathrm{C}$ and on a $12: 12 \mathrm{~h}$ irradiance of $300 \mu \mathrm{mo}$ photons $/ \mathrm{m}^{2} / \mathrm{s}$, and progressively adapted to $2.5 \%$ salinity by means of regular feeding (i.e. once a week) on $D$. tertiolecta.

\section{Live observations}

Live ciliates were observed for morphological identification using differential interference contrast (DIC) microscope with a Leitz Orthoplan microscope (Weitzlar, Germany), with the help of a compression device (Skovorodkin 1990) in order not to distort them as much as possible. For examination of the swimming behaviour, ciliates were observed in a Petri dish, under a stereomicroscope (WILD HEERBRUGG, Switzerland).

\section{Silver and Feulgen stainings}

Ciliates were treated for silver staining analysis with Champy's solution and then with silver nitrate according to Corliss (1953), to stain the ciliary pattern. Feulgen staining procedure was performed to reveal the nuclear apparatus, using a protocol modified from Dragesco and Dragesco-Kernèis (1986), after cell immobilization with celloidin-diethyl ether-alcohol solution.

\section{Scanning Electron Microscopy (SEM)}

The specimens were fixed in $2 \% \mathrm{OsO}_{4}$ for 40 min and glued on small coverslips (snipped from $1 \mathrm{x} 1$ $\mathrm{cm}$ size to the size of stub) previously coated with Poly-L-Lysine and subjected to consecutive dehydration in an ethanol series. Samples were critical point dried according to Nitla et al. (2019). Later, these coverslips were fixed onto SEM stubs with carbon conductive tape. Finally, the 
samples were sputter-coated with gold (Edwards sputter coater S 150B) and analyzed with JSM5410 scanning electron microscope.

\section{Transmission Electron Microscopy (TEM)}

Euplotes cells were fixed in $2.5 \%$ glutaraldehyde in $0.1 \mathrm{M}$ cacodylate buffer for $45 \mathrm{~min}$, rinsed in $0.1 \mathrm{M}$ cacodylate buffer and post-fixed in $1.5 \%$ aqueous osmium tetroxide in distilled water for 45 min at room temperature. Then cells were dehydrated and embedded in an Epon-araldite mixture as elsewhere described (Modeo et al. 2013a). The blocks were sectioned with an RMC PowerTome X ultra-microtome. Sections were placed on copper grids and stained with uranyl acetate and lead citrate. Samples were visualized using a JEOL JEM-100SX electron microscope.

\section{Measurements and recordings}

Morphometric data of properly oriented cells were taken by using both live and stained specimen preparations (i.e. Feulgen, silver staining, SEM).

Optical microscopy pictures were captured with a digital camera (Canon Power Shot S45) and used to obtain dimensions of living and stained ciliates. Morphometric measurements were analyzed with ImageJ 1.46r software (Ferreira and Rasband 2012).

Based on micrographs of living and stained cells, accurate schematic line drawings were produced with a procedure described by Montesanto (2015), which employed bitmap graphics with the GNU Image Manipulation Program (GIMP).

Terminology and systematics are mainly according to Curds (1975), Berger (2006), and Lynn (2008).

\section{DNA extraction and 18S rRNA gene sequencing}

Approximately 100-150 cells of KKR18_Esm strain were individually washed 3-5 times in sterile distilled water and fixed in $70 \%$ ethanol. Total genomic DNA extraction was performed using the NucleoSpin ${ }^{\mathrm{TM}}$ Plant II DNA extraction kit (Macherey-Nagel GmbH and Co., Düren NRW, Germany).

Polymerase chain reaction (PCR) was performed in a C1000 ${ }^{\mathrm{TM}}$ Thermal Cycler (Bio-Rad, Hercules, CA). The almost full-length of the 18S rRNA gene of Euplotes was amplified using the primer combination listed in Supplementary Table 1. High-fidelity Takara Ex Taq PCR reagents were employed (Takara Bio Inc., Otsu, Japan) according to the manufacturer's instructions. PCR cycles were set as follows: $3 \mathrm{~min} 94{ }^{\circ} \mathrm{C}, 35 \times\left[30 \mathrm{~s} 94{ }^{\circ} \mathrm{C}, 30 \mathrm{~s} 55^{\circ} \mathrm{C}, 2 \min 72{ }^{\circ} \mathrm{C}\right], 6 \min 72{ }^{\circ} \mathrm{C}$. PCR products were purified with the Eurogold Cycle-Pure Kit (EuroClone, Milan, Italy) and subsequently sent for direct sequencing to an external sequencing company (GATC Biotech AG, European Custom Sequencing Centre, Germany) by adding appropriate internal primers (see Supplementary Table 1).

\section{Whole genome amplification and assembly}


bioRxiv preprint doi: https://doi.org/10.1101/666461; this version posted June 11,2019 . The copyright holder for this preprint (which was not certified by peer review) is the author/funder, who has granted bioRxiv a license to display the preprint in perpetuity. It is made available under aCC-BY-NC-ND 4.0 International license.

Starting from around 5-10 cells, the total DNA material was amplified via whole-genome amplification (WGA) method, using REPLI-g Single Cell Kit (QIAGEN ${ }^{\circledR}$, Hilden, Germany). The cells of KKR18_Esm strain were washed in distilled water for three times and the last time in PBS buffer. Then, they were transferred in a $0.2 \mathrm{ml}$ eppendorf together with $4 \mu \mathrm{l}$ of PBS. The WGA protocol was completed following the manufacturer's instructions. The so obtained DNA material was processed with a Nextera XT library and sequenced at Admera Health (South Plainfield, USA), using Illumina HiSeq X technology to generate 75,510,798 reads (paired-ends 2x150 bp).

Preliminary assembly of resulting reads was performed using SPAdes software (v 3.6.0) (Bankevich et al. 2012).

\section{Mitochondrial genome assembly and annotation}

Contigs representing mitochondrial genome were identified using the Blobology pipeline (Kumar et al. 2013), and by tblastn searches using as queries proteins from reference genomes downloaded from NCBI, namely Oxytricha trifallax (JN383842) and Euplotes minuta (GQ903130). Contigs with a GC content comprised between $19 \%$ and $30 \%$, and a coverage higher than 1000X were selected and a subset of the extracted reads were assembled with SPAdes. We decided to use approximately $10 \%$ of the extraxted reads to artifically reduce the reads coverage, as coverage above 100x generally produces worse assemblies, due to an increasing number of exactly replicated sequencing errors, which create false branches in the deBruijn graph. The assembled genome was annotated using PROKKA 1.10 (Seemann 2014), setting the DNA translation codon table "4" and then manually checked.

\section{Endosymbiont genome assembly and annotation}

The presence of symbionts and host related microbial consortium was inspected in the preliminary assembly, using Barrnap (Seeman 2013) to detect 16S rRNA gene sequences, and manually checking all the contigs annotated as bacterial. This, in conjunction with the use of the Blobology pipeline as indicated above, allowed to select the contigs with a GC content lower than $25 \%$ and a coverage higher than 1000X for the assembly of the symbiont genome, and a subset (about 10\% of the extracted reads. See mitochondrial genome assembly and annotation in Materials and Method section) of the extracted reads were re-assembled with SPAdes. Closure of the circular genome was confirmed via PCR. Specific primers were designed on the basis of genome assembly and used for PCR amplification [Pingui_F162297 (5' - GTT GTA GCT CTC GGA TCG - 3'), Pingui_R436 (5' - GTA GAG CAT CTT CGA CTC G - 3')]; following internal primers were used for sequencing PCR products [Pingui_F163091 (5' - CTC AGA GCA CTC TGA GAT AG - 3'); Pingui_R199 (5' - GTT TAG CTC TTC CGA GAT CG - 3')]. PCR cycles were set as follows: 3 min $94{ }^{\circ} \mathrm{C}, 35 \times[30$ $\mathrm{s} 94{ }^{\circ} \mathrm{C}, 30 \mathrm{~s} 55^{\circ} \mathrm{C}, 2 \min 72{ }^{\circ} \mathrm{C}$ ], $6 \mathrm{~min} 72^{\circ} \mathrm{C}$. We relied on the same reagents, instruments and sequencing company cited above.

The assembled genome was annotated using PROKKA 1.10 (Seemann 2014), setting the DNA translation codon table " 4 " and then manually checking the results. The predicted protein-coding genes were also classified using NCBI COGs (Galperin et al. 2017), and compared with selected small genomes (Supplementary Table 2) and previously characterized Verrucomicrobia genomes 
bioRxiv preprint doi: https://doi.org/10.1101/666461; this version posted June 11,2019 . The copyright holder for this preprint (which was not certified by peer review) is the author/funder, who has granted bioRxiv a license to display the preprint in perpetuity. It is made available under aCC-BY-NC-ND 4.0 International license.

(Supplementary Table 3). The COGs thus obtained were used to carry out a Principal Component Analysis (PCA), using SciPy packages in Python, taking into account the numerosity of each COGs class.

\section{Phylogenetic and phylogenomic analyses}

The 18S rRNA gene of the host and the 16S rRNA gene of the newly characterized symbiont were aligned with the automatic aligner of the ARB software package version 5.5 (Westram et al. 2011) on the SSU ref NR99 SILVA database (Quast et al. 2013).

For the analysis on the host, 53 18S rRNA sequences of other members of the Euplotes genus, plus 7 sequences of other Spirotrichea as outgroup, were selected (dataset 1).

For the analysis on the symbiont, 98 16S rRNA sequences of other members of Verrucomicrobia were selected, plus 12 other sequences belonging to the superphylum Planctomycetes, Verrucomicrobia, Chlamydiae (PVC) (Wagner and Horn 2006) as outgroup (dataset 2). Sequences not shown in the tree are listed in (Supplementary Table 4).

After manual editing to optimize base pairing in the predicted rRNA stem regions in each dataset, the two alignments were trimmed at both ends to the length of the shortest sequence. A positional filter was applied to dataset 1 , to keep only those columns where the most conserved base was present in at least $10 \%$ of the sequences. Resulting matrices contained respectively 1,843 (dataset 1) and 1,456 (dataset 2) nucleotide columns, which were used for phylogeny and for the identity matrix calculation.

For each phylogenetic dataset, the optimal substitution model was selected with jModelTest 2.1 (Darriba et al. 2012) according to the Akaike Information Criterion (AIC). Maximum likelihood (ML) trees were calculated with the PHYML software version 2.4 (Guindon and Gascuel 2003) from the ARB package, performing 1,000 pseudo-replicates. Bayesian inference (BI) trees were inferred with MrBayes 3.2 (Ronquist et al. 2012), using three runs each with one cold and three heated Monte Carlo Markov chains, with a burn-in of 25\%, iterating for 1,000,000 generations.

For the phylogenomic analysis, 67 Verrucomicrobia (the endosymbiont plus 66 complete genomes from the genome taxonomy database (GTDB) (Parks et al. 2018)), and 4 other members of the PVC superphylum as outgroup, were used. A set of pre-aligned 120 single copy markers were employed (Parks et al. 2018), and the " $\mathrm{Ca}$. Pinguicoccus supinus" orthologs were identified by blastp search, then added to the existing alignments with MAFFT v7.123b (Katoh et al. 2013) and concatenated. A positional filter was applied to the concatenated genes according to Parks et al (2018), to obtain a total of 34,747 sites. The best substitution model was estimated with ProtTest (Darriba et al. 2011). RaxML (Stamatakis et al. 2014) was used to estimate ML phylogeny with 1000 bootstraps.

\section{Fluorescence microscopy}

Euplotes specimens were fixed for Fluorescence In Situ Hybridization (FISH) experiments in 2\% $\mathrm{OsO}_{4}$ and dehydrated after fixation with an increasing ethanol series for $10 \mathrm{~min}$ each. Specimens were processed for hybridization experiments according to previous publications (Boscaro et al. 2013a). 
bioRxiv preprint doi: https://doi.org/10.1101/666461; this version posted June 11,2019 . The copyright holder for this preprint (which was not certified by peer review) is the author/funder, who has granted bioRxiv a license to display the preprint in perpetuity. It is made available under aCC-BY-NC-ND 4.0 International license.

Preliminary FISH experiments were carried out using the generic probe for Verrucomicrobia EUB338 III (Daims et al. 1999) and the generic probe for Bacteria EUB338 (Amann et al. 1990). Only the EUB338 III probe showed slightly positive signal.

After 16S rRNA sequencing, we designed two probes on the 16S rRNA gene of the putative endosymbiont of Euplotes, EUB338 VII (5' - CTG CTG CCA TCC GTA GAT GT - 3') and Pingui_1174 (5' - ACT GAC TTG ACG TCA TCC TCA - 3’).

Both probes were tested in silico on the Ribosomal Database Project (RDP) (Cole et al. 2009) and SILVA database using TestProbe 3.0 (Quast et al., 2013), allowing 0 mismatches. The sequence of probe EUB338 VII matched 475 bacterial sequences in the RDP database, 19 of them registered as Verrucomicrobia and 139 registered as "unclassified bacteria". While, probe Pingui_1174 matched 220 bacterial sequences, 35 of them registered as Verrucomicrobia and 180 registered as "unclassified bacteria". Sequences of these two new probes were deposited into probeBase database (Greuter et al. 2016).

Those probes were used to perform additional FISH experiments to confirm the presence of that particular species of Verrucomicrobia inside the host.

Hybridized slide preparations were observed under a Zeiss AxioPlan fluorescence microscope (Carl Zeiss, Oberkochen, Germany) equipped with an HBO 100W/2 mercuric vapor lamp at the following UV wavelengths: $495 \mathrm{~nm}, \sim 550 \mathrm{~nm}$. Digital images were captured at different magnifications (40X and 100X) by means of a dedicated software (ACT2U, version 1.0).

\section{Endosymbiont 16S rRNA gene screening on IMNGS}

Diversity and environmental distribution of the bacterial endosymbiont was estimated using the IMNGS on-line platform (Lagkouvardos et al. 2016), which screens most of 16S rRNA gene amplicon datasets available. A query at 95\% similarity was performed using the endosymbiont's full-length 16S rRNA gene and related Puniceicoccaceae sequences (accession numbers: AB073978, AB372850, AB614893, AB826705, CP001998, DQ539046, EU462461, KT751307, JQ993599, JQ993517, Y19169, for their 16S rRNA full-length gene phylogenetic position see Figure 7). The obtained sequences were longer than $300 \mathrm{bp}$ and were divided into three different groups to perform phylogenetic analysis according to the $16 \mathrm{~S}$ rRNA gene hypervariable regions V1-V2, V4-V6, and V7-V8. Sequences were clustered in OTUs with a 99\% threshold similarity using UCLUST (Edgar 2010), then they were aligned with MUSCLE (Edgar 2004), and FastTree (Price et al. 2009) was employed to infer phylogenetic analyses. Thereafter, environmental distribution was investigated using the endosymbiont sequence as query and their abundances were calculated.

\section{Results}

\section{Description of Euplotes vanleeuwenhoeki sp. nov. (Figures 1-5, Table 1)}


Subclass Euplotia Jankowski, 1979

Order Euplotida Small and Lynn, 1985

Family Euplotidae Ehrenberg, 1838

Genus Euplotes Ehrenberg, 1831

Diagnosis Size in vivo $(X \pm \mathrm{SD}) 49.1 \pm 4.7 \times 32.7 \pm 3.8 \mu \mathrm{m}$. Dorso-ventrally flattened, with an oval to ellipsoidal shape. "C-shaped" or "3-shaped" macronucleus and a single micronucleus.

Dargyrome of double-eurystomus type, 7-8 dorsal ridges, with 13-14 dikinetids in the mid-dorsal row. About 22-29 adoral membranelles. Cirri pattern: 10 fronto-ventral, 5 transverse, 2 marginal, and 2 caudal cirri. Freshwater.

Type locality Freshwater emissary of Kolleru Lake, in the proximity of Allapadu-Kolletikota road, West Godavari District of Andhra Pradesh, India. This species inhabits freshwater sites covered by Eichhornia sp. (water hyacinth).

Etymology We dedicated this new species of Euplotes to Antoni Philips van Leeuwenhoek (16321723), Dutch optician and naturalist. Van Leeuwenhoek is best known for his pioneering work in microscopy and for his contributions toward the establishment of microbiology as a scientific discipline. For this reason, he is also known as "the father of microbiology", being one of the first microscopists and microbiologists.

Type material The slide with the silver-stained holotype specimen (indicated with a black circle of ink on the coverslip) and some paratype specimens has been deposited in the collection of the "Museo di Storia Naturale dell'Università di Pisa" (Calci, Pisa, Italy) with registration number "2019-1". Two slides with silver-stained paratype specimens (indicated with a black circle of ink on the coverslip) were deposited in the collection of the Natural History Museum of London (registration number: NHMUK 2019.3.16.1), and in the collection of the Unit of ZoologyAntropology of the Department of Biology at Pisa University (registration number: UNIPI_2019-1), respectively.

Morphological description Size $(X \pm \mathrm{SD})$ in vivo $49.1 \pm 4.7 \times 32.7 \pm 3.8 \mu \mathrm{m}$. Size after silver staining $45.6 \pm 3.1 \times 29.1 \pm 4.1 \mu \mathrm{m}$. Cell reduction after fixation: $8 \%$. Cells dorso-ventrally flattened, with an oval to ellipsoidal shape (Fig.1). Right margin usually straight or slightly convex, left margin tapered in the anterior, becoming convex in the mid-body, and both ends are rounded (Fig.1a). Ciliates can crawl on the substrate and swim freely in the medium. Cytoplasm transparent with some roundish, yellow granules; few food vacuoles containing green algae and bacteria (Fig. 1b, c). Single contractile vacuole located at the level of transverse cirri (Fig. 1b). On dorsal side, cortical ampules arranged around each bristle form conspicuous rosettes with their cortical insertions (Fig. 1c). Macronucleus (Ma) "C-shaped" or "3-shaped" (size: $36.6 \pm 4.5 \times 5.7 \pm 1.0 \mu \mathrm{m}$ ) with irregularly dense chromatin, and a single, roundish micronucleus (Mi) (diameter: $2.0 \pm 0.2$ $\mu \mathrm{m})$, usually located in a small depression close to Ma (Fig. 1d).

Dargyrome of the double-eurystomus type, with two rows of polygonal alveoli between each pair of dorsolateral kineties (Figs 1e, g, i). Dorsal surface crossed by three longitudinal furrows (i.e. right marginal, median, and left marginal), reaching the posterior region of the cell (Fig. $1 \mathrm{~g}$ ). Six 
bioRxiv preprint doi: https://doi.org/10.1101/666461; this version posted June 11,2019 . The copyright holder for this preprint (which was not certified by peer review) is the author/funder, who has granted bioRxiv a license to display the preprint in perpetuity. It is made available under aCC-BY-NC-ND 4.0 International license.

dorsolateral kineties, three in correspondence of dorsal furrows, carrying short bristle-like cilia (Fig. $1 \mathrm{~g}$ ); the leftmost kinety is placed in a slightly ventrolateral position (Fig. 1j). Mid-dorsal row containing up to 13-14 dikinetids (Fig. 1e).

On the ventral side, invariably 10 frontoventral cirri (FVC), 5 transverse cirri (TC), 2 well developed caudal cirri (CC), and 2 marginal cirri (MC) on the left side, in the posterior end of the cell (Fig. 1f, h, j). Argyrome is highly irregular (Figs 1h, j) and the ventral surface presents five longitudinal ridges hosting cirral insertions; the three ridges on the left are more prominent (Fig. 1h). The first and the fifth ridges reach the posterior part of the cell at level of the $\mathrm{CC}$, while the other three ridges terminate beyond the TC (Fig. 1h).

Peristome narrow, extending for about $63 \%$ of the body length, on the ventral side. Adoral zone comprising 22-29 membranelles (AZM), starting at the top of the cell, travelling down along the left side and reaching the first ventral ridge, with a slight curve towards the centre of the body, at level of transverse cirri (Fig. 1h). The paroral membrane appreciable in silver stained specimens (Fig. 1f), and in SEM-processed specimens (Fig. 1j), although carrying cilia shorter than those forming the AZM. All morphometric data are shown in Table 1.

Fine structure The fine structure of E. vanleeuwenhoeki (Fig. 2) matches that of the other previously described Euplotes species, in general showing typical features (Fauré-Fremiet and Andre 1968; Nobili and Rosati Raffaelli 1971; Kloetzel 1974; Ruffolo 1976; Modeo et al. 2005; Schwarz et al. 2007). Under the cell cortex flat alveoli are present (Figs 2a-f, h-j). On the dorsal side, somatic cilia consisting of dikinetids (Figs 2a, c) are deeply inserted into the cytoplasm $(\sim 1.4$ $\mu \mathrm{m}$ ); from kinetosomes only a single bristle-like cilium emerges (Fig. 1c, g). In the bristle pit, some filamentous material is sometimes visible. (Fig. 2b). This is likely released by cortical ampules, the typical exocytotic organelles associated with both Euplotes dorsal bristle and compound ciliary organelles of the ventral surface; these organelles probably represent specialized compartments of the cell in which materials that need to be excreted are accumulated, stored, and released according to the requirements of the different Euplotes species (Rosati and Modeo 2003). Ampules associated with dorsal bristles of E. vanleeuwenhoeki appear elongated (size: 1.6 x $0.3 \mu \mathrm{m}$ ) and usually empty possibly also due to fixation procedure (Fig. 2c). Membranelles bordering the upper and left side of the oral cavity are separated from each other by ridges (Fig. 2d). Each membranelle of AZM consists of three rows of cilia: two equally long plus a shorter one (Fig. 2d). Axonemes contain many electron dense granules (Fig. 2d). Kinetosomes of membranelles are linked at their base. (Fig. 2e). A polystichomonad paroral membranelle is inserted on the right margin of the terminal oral cavity; its cilia appear linked to each other at the kinetosome level (Figs 2d, e). Many flat, electron lucid pharyngeal disks are associated to the base of the cytostome, in correspondence of AZM bases (Figs 2e, f). Macronucleus contains large piece of chromatin and large nucleoli (Figs 2f, g). Micronucleus consists of fine chromatin (Fig. 2g). A single contractile vacuole with an irregular silhouette is observed near a transverse cirrus (Fig. 2h). On the ventral side, kinetosomes of cilia forming cirri contain large electron dense granules (Fig. 2i). Mitochondria show variable shape and size and typical tubular cristae (Figs 2b, c, e, f). Lipidic reserve substances consist of large granules; polysaccharidic reserve substances are represented by rosettes of glycogen abundantly and sparsely distributed throughout the cytoplasm (Figs $2 \mathrm{~g}$, h). Large, irregular phagosomes are also present, with various content in different digestion stages (Fig. 2j). 
bioRxiv preprint doi: https://doi.org/10.1101/666461; this version posted June 11,2019 . The copyright holder for this preprint (which was not certified by peer review) is the author/funder, who has granted bioRxiv a license to display the preprint in perpetuity. It is made available under aCC-BY-NC-ND 4.0 International license.

Numerous, morphologically similar endosymbiotic bacteria, presenting variable shape and size, are located in the cytoplasm (Figs 2, 5): a detailed morphological description is presented below.

Gene sequence The 18S rRNA gene sequence of E. vanleeuwenhoeki (strain KKR18_Esm) obtained from PCR resulted 1,849 bp long, and it has been deposited in NCBI GenBank database with the accession number KY855568. The 18S rRNA gene sequence of $E$. vanleeuwenhoeki showed the highest identity with sequences of Euplotes cf. antarcticus (FJ998023) and E. trisulcatus, (EF690810): 99.0\% (3 gaps, 16 mismatches) and 98.7\% (13 gaps, 19 mismatches), respectively (Supplementary Table 5).

Phylogeny The 18S rRNA gene-based phylogeny placed E. vanleeuwenhoeki in the so-called "clade A" of genus Euplotes (Syberg-Olsen et al. 2016; Boscaro et al. 2018), clustering together with Euplotes cf. antarcticus (FJ998023; Gao and Song unpublished) and with E. trisulcatus, (EF690810; Schwarz and Stoeck unpublished), with high statistical support (1.00/100). This clade resulted sister to a clade comprising sequences attributed to E. charon (AF492705), E. magnicirratus (AJ549210), and E. euryhalinus (EF094968, JF903799) group (see later discussion on species attribution). See Figure 3.

Mithocondrial genome The assembly resulted in a single linear contig 41,682 bp long with a GC content of $\sim 0.25 \%$, representing the complete mitochondrial genome of E. vanleeuwenhoeki. It has been deposited in NCBI GenBank database with the accession number MK889230. It contains 36 protein coding genes and 16 tRNAs. The genome presents the 16S rRNA and 23S rRNA genes split in two loci, with the 23S rRNA further divided in two genes, separated by a short interposing region of approximately 350 nucleotides (Fig. 4). The predicted direction of the transcription is away from a central region constituted of low-complexity repeated units (Fig. 4). The splitting of the rRNA genes and the presence of a central repeat region is a common feature shared by all the so far investigated Euplotes mitochondrial genomes, (De Graaf et al. 2009) and by the one of Oxytricha trifallax (Swart et al. 2011). The novel genome shows an overall synteny with the mitochondrion of of Euplotes minuta, Euplotes crassus (De Graaf et al. 2009) and Oxytricha trifallax (Swart et al. 2011), with the exception of the two terminal regions, which show a different structure in respect of the other three genomes (Fig. 4).

Microbial consortium The screening of the preliminary assembly for bacterial 16S rRNA genes allowed to identify the presence of a single microorganism associated to E. vanleeuwenhoeki. Further analyses proved that this bacterium was localized in the cytoplasm of the ciliate, and that it was a novel endosymbiont we named " $\mathrm{Ca}$. Pinguicoccus supinus" (see "Endosymbiont characterization" section). No other bacterial 16S rRNA gene sequence was detected in the sequencing reads. Moreover, most of the other contigs tha were preliminary flagged as bacterial from the best megablast hit in the Blobology pipeline actually belonged to the mitochondrial or nuclear genome of Euplotes, or they were short $(<600 \mathrm{bp})$ or at a very low coverage $(<30 \mathrm{x})$, thus were considered as from undetermined origin, possibly representing only minor contaminations, and were discarded (Supplementary Table 6).

\section{Endosymbiont characterization: “Candidatus Pinguicoccus supinus” gen. nov. sp. nov.} (Figures 5-10) 
bioRxiv preprint doi: https://doi.org/10.1101/666461; this version posted June 11,2019 . The copyright holder for this preprint (which was not certified by peer review) is the author/funder, who has granted bioRxiv a license to display the preprint in perpetuity. It is made available under aCC-BY-NC-ND 4.0 International license.

Morphological description "Ca. Pinguicoccus supinus" gen. nov. sp. nov. is a roundish-ovoid bacterium detected in the cytoplasm of E. vanleeuwenhoeki (Fig. 5) with a diameter of 1.3-2.3 $\mu \mathrm{m}$ (on average $(X \pm \mathrm{SD}): 1.9 \pm 0.3 \mu \mathrm{m})$. It usually lies beneath the ciliate cortex, often in clusters of several individuals (Fig. 5a). Although the most common bacterial shape observed is rounded (Fig. 5b), sometimes ovoid (Fig. 5c) and irregular (Figs 5d, e) individuals can be detected as well. This cell shape plasticity might possibly be due to the pressure exerted by the host cytoplasm on the ductile body of the bacterium. No symbiosome is observed to isolate the endosymbiont from ciliate cytoplasm (Fig. 5). "Ca. Pinguicoccus supinus" is delimited by a double membrane with a thin space between the two layers possibly corresponding to the paryphoplasm (Fig. 5b), the intracellular space defined for the first time by Linsday and colleagues (Lindsay et al. 2001). In several individuals, the increase of membrane area is visible: in some cases, a slight invagination of the inner membrane occurs (Figs 5b-d), while in others the evagination of the external membrane can be observed (Fig. 5d-f). In the latter case, different inclusions of unknown origin have also been observed in the space between inner and outer membrane (Fig. 5d, e). The bacterial cytoplasm (possibly corresponding to the pirellulosome; Lindsay et al. 2001) generally appears homogeneous and a compact, more electrondense region, likely corresponding to bacterial nucleoid, is visible in some bacteria with an eccentric localization (Fig. 5d, e, h, i). Occasionally, specimens show a very emphasized folding of membrane area, making it difficult to recognize whether the folding comes from the inner or the outer membrane (Fig. $5 \mathrm{~g}$ ). Out of a total of $\sim 80$ observed endosymbionts observed in thin section, roughly one third are in proximity (i.e. at a distance of $\sim 0.25 \mu \mathrm{m}$ or less) of mitochondria (Figs. 5a-c, f, i) and one fifth are in proximity to lipid droplets (Figs 5e, g, h). Intriguingly, in these cases, bacterial double membrane is even seen somehow in direct contact with mitochondrial external membrane (Fig. 5c) and lipid droplets (Fig. 5h). "Ca. Pinguicoccus supinus" reproduces in the host cytoplasm by binary fission and has, apparently, a typical symmetrical division (Fig. 5i).

Gene sequence The 16S rRNA gene sequence of " $\mathrm{Ca}$. Pinguicoccus supinus" resulted 1,517 bp long and has been deposited in NCBI GenBank database with the accession number MK569697. It showed highest identity $(78.8 ; 78.3 \% ; 78.2 \%)$ with sequences from uncultured bacteria (JQ993517 and MNWT01000005; AB826705; AY571501 respectively). The best hit with a cultured bacterium was $76.8 \%$ with Ruficoccus amylovorans (KT751307) (Verrucomicrobia, Opitutae,

Puniceicoccaceae). In general, identity values with the closest relatives resulted quite low (75.778.8\%) (Supplementary Table 7).

Genome assembly The assembly of the symbiont's genome resulted in a single circular chromosome, 163,218 bp long with a GC content of $25.1 \%$. The complete genome sequence of " $\mathrm{Ca}$. Pinguicoccus supinus" has been deposited in NCBI GenBank database with the accession number CP039370. It contains 168 protein coding sequences, 34 tRNAs and a single rRNA operon composed by a 16S rRNA gene, a 23S rRNA gene and a 5S rRNA gene. The overall coding percentage is $92.3 \%$. The ORFs were subjected to clusters of orthologous groups (COGs) classification, and 131 COGs were identified, most of which were related to the general cellular function categories (J, O, M and I, for a total of 112 COGs - Supplementary Table 8). This repertoire is a subset of the previously characterized Verrucomicrobia, i.e. without any exclusive metabolic pathway or gene (Supplementary Table 3). Considering the drastic genome reduction of "Ca. Pinguicoccus supinus", we decided to perform comparative analyses using as reference the few other symbiotic bacteria with highly reduced genome although belonging to unrelated lineages 
bioRxiv preprint doi: https://doi.org/10.1101/666461; this version posted June 11, 2019. The copyright holder for this preprint (which was not certified by peer review) is the author/funder, who has granted bioRxiv a license to display the preprint in perpetuity. It is made available under aCC-BY-NC-ND 4.0 International license.

(i.e. Bacteroidetes, Alphaproteobacteria, Gammaproteobacteria, Betaproteobacteria). PCA was able to capture almost $56 \%$ of the whole variance (Fig. 6a) in the COG dataset (Component one $32 \%$ of explained variance, and Component two $24 \%$ ).

While almost all the bacteria with highly reduced genome cluster together (Fig. 6a), the variance explained by the first component positions " $\mathrm{Ca}$. Pinguicoccus supinus" remarkably far from them. This component is mainly correlated with the COG classes Q - Secondary metabolites biosynthesis, transport and catabolism (0.36), I - Lipid transport and metabolism (0.34), and K - Transcription (0.33). The variance explained by the second component separates " $\mathrm{Ca}$. Zinderia insecticola" from the other bacteria with highly reduced genome. This component is mainly correlated with COG classes P - Inorganic ion transport and metabolism (0.42), H - Coenzyme transport and metabolism (0.39), and C - Energy production and conversion (0.33) classes.

The COG analysis also showed the presence of a set of 33 genes shared by all the small genome bacteria in analysis (Figs 6b, c), mostly related to DNA replication, transcription, and translation. Although the metabolic capability of " $\mathrm{Ca}$. Pinguicoccus supinus" is, in general, similar to that of other highly reduced genomes (88\% of COGs shared with at least another analysed genome; Figs 6b, c) (McCutcheon et al. 2012; Moran and Bennett 2014), the novel genome lacks the capability to synthesize any amino acids. Moreover, no catalytic subunit of the DNA polymerase was identified. “Ca. Pinguicoccus supinus" possesses 30 genes (12\% of the total retrieved COGs in this bacterial genome) that are absent in all the other tiny genomes, mostly related to COG classes I (lipid transport and metabolism) and M (cell wall/membrane/envelope biogenesis). In general, with respect to the other analyzed bacteria, this endosymbiont includes a richer set of genes involved in fatty acid biosynthesis, in glycosylation and glycan modification (Supplementary Table 8).

Phylogeny and phylogenomics The $16 \mathrm{~S}$ rRNA gene-based phylogeny showed " $\mathrm{Ca}$. Pinguicoccus supinus" as a member of the family Puniceicoccaceae (Verrucomicrobia, Opitutae) (Fig. 7). It clustered with sequences from uncultured organisms, forming a clade related to the genera Coraliomargarita, "Fucophilus", Cerasicoccus, and Ruficoccus (Fig. 7). The long branch of "Ca. Pinguicoccus supinus" suggests a higher evolutionary rate with respect to related Verrucomicrobia. Moreover, we observed that the inclusion of the " $\mathrm{Ca}$. Pinguicoccus supinus" sequence in the Verrucomicrobia tree reduces the values of statistical supports for the nodes of the Puniceicoccaceae clade (data not shown). This is consistent with the occurrence of a long branch attraction phenomenon between " $\mathrm{Ca}$. Pinguicoccus supinus" and the outgroup, which destabilizes Puniceicoccaceae despite high taxon sampling (Bergsten 2005).

The result of the phylogenomic analysis is fully consistent with the phylogeny of the 16S rRNA gene, confirming the position of the endosymbiont inside the phylum Verrucomicrobia and in the class Opitutae (Fig. 8). "Ca. Pinguicoccus supinus" clustered together with uncultured organisms (GB_GCA_001872735,GB_GCA_002309885,GB_GCA_002336265), in a clade related to Coraliomargarita akajimensis (RS_GCF_000025905), and thus inside the family Puniceicoccaceae (Fig. 8).

Localization inside host cell FISH experiments showed $100 \%$ of E. vanleeuwenhoeki cells positive to specifically designed probes for " $\mathrm{Ca}$. Pinguicoccus supinus" (Fig. 9). The number of endosymbionts per host cell ranged from 12 to 36 bacteria ( $X \pm \mathrm{SD}: 25.1 \pm 7.3 ; n=16)$. The 
bioRxiv preprint doi: https://doi.org/10.1101/666461; this version posted June 11,2019 . The copyright holder for this preprint (which was not certified by peer review) is the author/funder, who has granted bioRxiv a license to display the preprint in perpetuity. It is made available under aCC-BY-NC-ND 4.0 International license.

symbionts showed a peculiar pattern of distribution in almost all the observed Euplotes cells: beneath the cortex of the host, in clusters of several bacteria grouped at one side of the cell (Fig. 9c), or more commonly at the two poles (Fig. 9f). These observations support data from TEM analysis, showing " $\mathrm{Ca}$. Pinguicoccus supinus" generally lying close to the cortex and forming clusters with other conspecifics.

Diversity and environmental screening of the endosymbiont The IMNGS platform was used to investigate the molecular diversity and environmental distribution of sequences showing high identity with the novel endosymbiont of Euplotes. The 16S rRNA gene of the endosymbiont was queried at $95 \%$ similarity threshold, and a total number of 4,572 sequences were obtained and subsequently used to investigate the molecular diversity of 16S rRNA gene hypervariable regions. Sequences were clustered in 90 OTUs with $99 \%$ threshold identity, then OTUs were grouped according to their hypervariable region in V1-V2, V4-V6 and V7-V8, and phylogenetic trees were inferred accordingly (Fig. 10). Phylogenetic trees showed that six diverse groups can be distinguished for all hypervariable regions considered, and their phylogenetic relations are in agreement with those shown by the full-length 16S rRNA gene phylogenetic reconstruction (Fig. 10). The first group (red) includes the novel endosymbiont and related sequences (AB614893, JQ993517; Fig. 7), the second one (violet) is formed by sequences from uncultured bacteria (JQ993599, AB826705), the third one (purple) consists of a single uncultured bacterium (EU462461), the fourth one (green) includes Coraliomargarita akajimensis (CP001998), "Fucophilus fucodainolyticus" (AB073978), and Puniceicoccus vermicola (DQ539046), the fifth one (yellow) has Cerasicoccus frondis (AB372850) and Ruficoccus amylovorans (KT751307), and the last one (blue) includes just epixenosomes from Euplotidium arenarium (Y19169) (Fig. 10). The IMNGS environmental screening also showed that metagenomic samples positive to " $\mathrm{Ca}$. Pinguicoccus" were very limited in number, namely $0.01 \%$ of total samples. Indeed, the related sequences were present in just 32 out of a total of 303,362 samples (Supplementary Table 9). The environmental origin of positive samples is reported in Supplementary Table 9. Positive hits originated from very diverse samples, such as seawater, wastewater, microbial mats, but also potential host organisms, such as shrimps and plants (Supplementary Table 9). However, the overall abundance of positive hits was extremely low and always below $1 \%$ within each sample. The highest abundance was found in samples originating from a study on wastewater (Al-Jassim et al. 2015), where "Ca. Pinguicoccus" abundance ranged between 0.005 and $0.752 \%$ (Supplementary Table 9).

\section{Discussion}

\section{Next generation taxonomy}

The present work aims to introduce and describe an innovative approach to the characterization of living beings, integrating the holobiont concept into traditional and integrative taxonomy leveraging the power of high-throughput DNA sequencing. We propose for this approach the name "next generation taxonomy".

To exemplify the concept of "next generation taxonomy" applied to holobionts, we used the ciliate E. vanleeuwenhoeki sp. nov. and its symbiont, “Ca. Pinguicoccus supinus” gen. nov., sp. nov., as a 
bioRxiv preprint doi: https://doi.org/10.1101/666461; this version posted June 11, 2019. The copyright holder for this preprint (which was not certified by peer review) is the author/funder, who has granted bioRxiv a license to display the preprint in perpetuity. It is made available under aCC-BY-NC-ND 4.0 International license.

case study. In the following discussion, we propose an updated pipeline for the description of holobionts starting with the sequential description of each biont of the system.

\section{First biont: Euplotes vanleeuwenhoeki}

Comparison with congeners Euplotes vanleeuwenhoeki showed morphological and molecular affinity with other members of the genus, such as E. antarcticus (Fenchel and Lee 1972; Petz et al. 1995), E. trisulcatus (Carter 1972), E. euryhalinus (Valbonesi and Luporini 1990a), E. charon (Song and Packroff 1997; Shao et al. 2010), and E. magnicirratus (Carter 1972). Indeed, they share the same dargyrome and frontoventral cirri patterns (for details see Table 2), and clustered together in our molecular phylogeny (Fig. 3). As for its morphology, E. vanleeuwenhoeki was particularly similar to E. trisulcatus (Carter 1972). Nevertheless, the combination of several characters (i.e. posterior end rounded versus pointed; peristome length, number of AZM, number of dikinetids in mid-dorsal row - for details see Table 2), the overall body shape, the type of habitat (freshwater $v s$ marine), and the 18S rRNA gene sequence supported its attribution to a novel species.

Unfortunately, the sequences closest to that of E. vanleeuwenhoeki in our phylogeny reconstruction (i.e. E. magnicirratus - AJ549210 (Petroni et al. 2002); E. charon - AF492705 (Li and Song 2006); E. euryhalinus - EF094968 (Vallesi et al. 2008), JF903799 (Keerthi and Reddy unpublished); E. trisulcatus EF690810 (Schwarz and Stoeck unpublished), Euplotes cf. antarcticus - FJ998023 (Gao and Song unpublished) are not accompanied by any morphological description. Consequently, data used in our morphometric comparison inevitably derive from previous, exclusively morphological, studies (i.e. Carter 1972; Petz et al. 1995; Valbonesi and Luporini 1990a; Song and Packroff 1997; Shao et al. 2010). Moreover, there is no certainty that above-mentioned Euplotes-derived sequences have been properly attributed to the correct ciliate species; thus, a certain cautiousness is recommended until a comprehensive redescription of such organisms, joining morphology and molecular data, is performed. In this somehow unclear landscape, for the sake of completeness, we decided to include in our comparison among different Euplotes species (Table 2) also E. charon, because it shares some basic features with E. vanleeuwenhoeki, (i.e. dargyrome, and frontoventral cirri pattern), although the phylogenetic position of this species is far from being resolved. Indeed, the sequence AF492705, under the name of E. charon, is not linked to any morphological description (Li and Song 2006); this sequence was used by Shao and colleagues (Shao et al. 2010) as molecular reference in their redescription of E. charon, for which, unfortunately, they used a different Euplotes strain for morphological analysis. However, there are several other available sequences that are named after E. charon, but they all are not supported by any morphological data (i.e. AJ305249, Petroni et al. 2002; JF694043, Huang et al. 2012; FJ87077-80, Huang and Song unpublished) and these sequences cluster far away from E. vanleeuwenhoeki. A critical revision of the species E. charon using at least integrative taxonomy is consequently highly recommended.

As a general remark, E. vanleeuwenhoeki share with many other species the plesiomorphic condition of the genus, i.e. the occurrence of $10 \mathrm{FVC}$ and a double dargyrome of eurystomus-type (e.g.: E. alatus, E. antarcticus, E. balteatus, E. charon, E. crenosus, E. curdsi, E. enigma, E. euryhalinus, E. focardii, E. harpa, E. inkystans, E. magnicirratus, E. neapolitanus, E. octocirratus, E. palustris, E. parabalteatus, E. platysoma, E. plicatum, E. polycarinatus, E. qatarensis, E. quinquecarinatus, E. rariseta, E. trisulcatus, and E. tuyraui). Although these two features are 
bioRxiv preprint doi: https://doi.org/10.1101/666461; this version posted June 11,2019 . The copyright holder for this preprint (which was not certified by peer review) is the author/funder, who has granted bioRxiv a license to display the preprint in perpetuity. It is made available under aCC-BY-NC-ND 4.0 International license.

always reported in morphological description, due to their plesiomorphic status they are of limited use for taxonomic identification. As an example, some authors (Jones and Gates 1994) even proposed to synonymise almost all species possessing $10 \mathrm{FVC}$ and a double dargyrome under the name of E. charon. Obviously, nowadays, this proposal is not acceptable on the basis of molecular data (Boscaro et al. 2018; Lian et al. 2018) and because of other morphological features characterizing some of the organisms (e.g. dorsal furrows/ridges, and body shape and proportions). It has been proved that, in many cases, this ancestral condition underwent severe, independent modifications during the evolutionary history of the genus (Petroni et al. 2002; Syberg-Olsen et al. 2016). Indeed, the double dargyrome evolved in other different patterns, such as "single", "double patella-type", "multiple" (Carter 1972), and "complex", in many distinctive events (Syberg-Olsen et al. 2016). The dargyrome modification was explained either by increasing in number or by unification of alveoli (Valbonesi and Luporini 1995; Syberg-Olsen et al. 2016). It is not by chance that some Euplotes species present a great phenotypic plasticity, determined by particular physiological and/or ecological conditions, such as the presence of a predator and/or food availability (i.e. E. focardii (Valbonesi and Luporini 1990b), E. balteatus (Tuffrau 1964), E. octocarinatus (Kuhlmann and Heckmann 1994; Kopp and Tollrian 2003), and E. variabilis (Tuffrau et al. 2000)). Similarly, one or more FVC were independently lost many times, as also evidenced by the vestiges still detectable in some Euplotes species (Washburn and Borror 1972; Petroni et al. 2002; Jiang et al. 2010; Syberg-Olsen et al. 2016).

Mitochondrial genome Ciliates possess very peculiar mitochondrial genomes, being among the first to be identified as linear (Suyama and Miura 1968; Morin and Cech 1986) and showing several split rRNA genes (Schnare et al. 1986) and protein genes (Burger et al. 2000). To our best knowledge, in ciliates, the set of potentially split genes in the mitochondrial genome includes nadl, $n a d 2, r p s 3, r n l$ and $r n s$. This list now includes the coxl gene, which is split in E. vanleeuwenhoeki. Considering that the splits in nadl, nad2, rps3, rnl and $r n s$ genes occur approximately at the same positions in the mitochondrial genomes of Spirotrichea, it has been hypothesized they could be present in the last common ancestor of Euplotes and Oxytricha (Swart et al. 2011). However, since the coxl gene is split only in the E. vanleeuwenhoeki genome, it is likely that this represents a more recent event. The occurrence of multiple and evolutionary independent split genes in ciliates could be considered indicative of a possible inherently higher tolerance to split events in mitochondrial genes in these organisms. The mitochondrial genome of $E$. vanleeuwenhoeki shows a high level of colinearity with the other two available Euplotes mitochondrial genomes. In addition, all Euplotes share a good colinearity with $O$. trifallax (two single-gene inversions and one single-gene transposition). Since the amino acid substitution rates in ciliate mitochondrial genomes appear to be high (Swart et al. 2011), this result enforces the idea that mitochondrial genome colinearity can be employed in phylogenetic analysis as a valid supporting feature to define the systematics of ciliates, or to distinguish different taxonomic levels among very related species using the non-colinear terminal regions (Blanchette et al. 1996; Boore and Brown 1998). Indeed, mitochondrial genes, such as coxl, cox2 and rns, are being increasingly used in taxonomy, both for phylogenetic analysis (Dumilag et al 2018), and for discriminating between species with similar morphological features. For example, mtDNA genes have been employed to reveal several cryptic species in Ciliophora (Barth et al. 2006; Doerder 2019) and metazoan such as annelids (Nygren et al 2018) and insects (Ya'cob et al 2017), or to discriminate between subspecies of the bee Apis mellifera (Ilyasov et al 2016). The limited number of available mitochondrial genome sequences of ciliates currently does 
bioRxiv preprint doi: https://doi.org/10.1101/666461; this version posted June 11,2019 . The copyright holder for this preprint (which was not certified by peer review) is the author/funder, who has granted bioRxiv a license to display the preprint in perpetuity. It is made available under aCC-BY-NC-ND 4.0 International license.

not allow to perform phylogenetic analyses based neither on sequences nor on colinearity. Nevertheless, we predict that such analyses will be extremely helpful, in the future, to resolve phylogenetic and taxonomic issues as already occurred in other taxa (e.g. metazoa) in which more sequences are already available (Lavrov et al. 2004; Cameron 2014). We expect the same for ciliates as soon as a sufficient number of novel mitochondrial genome sequences will be available.

Symbiosis with a Verrucomicrobia member Members of genus Euplotes are known to host symbiotic eukaryotes, mutualistic such as endocellular algae (Diller and Kounaris 1966; Lobban et al. 2005), or opportunistic such as microsporidia (Fokin et al. 2008) and trypanosomes (Fokin et al. 2014). Moreover, Euplotes species display a certain attitude to harbor one (Heckmann et al. 1983; Vannini et al. 2004, 2013), or even multiple bacterial symbionts, this second condition being more common if the ciliate presents the obligate symbiosis with the betaproteobacterium Polynucleobacter necessarius (Heckmann and Schmidt 1987; Boscaro et al. 2012, 2013b; Schrallhammer et al. 2013; Vannini et al. 2010, 2014; Boscaro et al. 2018; Chiellini et al. 2019). In those cases, the secondary or tertiary symbionts, if present, frequently belong to

Alphaproteobacteria, e.g. Rickettsiaceae (Schrallhammer et al. 2013; Vannini et al. 2014, Lanzoni et al., 2019) or " $C a$. Midichloriaceae" (Vannini et al. 2010; Boscaro et al., 2013b; Senra et al. 2015). Also, Gammaproteobacteria were retrieved in different Euplotes species (Schrallhammer et al. 2011; Boscaro et al. 2012; Chiellini et al. 2019; Vallesi et al. 2019).

To date, "Ca. Pinguicoccus supinus" as endosymbiont of $E$. vanleeuwenhoeki constitutes a unicum, being the first member of Verrucomicrobia with a highly reduced genome, and also the first found as endosymbiont of a protist. Indeed, bacteria of the phylum Verrucomicrobia are mostly free-living organisms, nearly ubiquitous, present both in the soil and in wet environments (Zhang and Xu 2008; Freitas et al. 2012), and often retrieved in extreme habitats (Pearce et al. 2003; Hou et al. 2008). Little is known about Verrucomicrobia living as obligate symbionts, which at present were described in nematodes (Vandekerckhove et al. 2000), echinoderms (Sakai et al. 2003), squids (Collins et al. 2012), and in gut of different metazoans (Yildirim et al. 2010; Romero-Pérez et al. 2011), including humans (Wang et al. 2005). The only other case of association of Verrucomicrobia with protists is the symbiosis between the ciliate Euplotidium and the so-called epixenosomes (Rosati et al. 1998; Petroni et al. 2000; Modeo et al. 2013b), which are verrucomicrobial ectosymbionts able to extrude and defend their host against predators (Rosati et al. 1999).

\section{Second biont: "Candidatus Pinguicoccus supinus"}

Endosymbiont morphology The morphology of some PVC members is renown to be peculiar. Indeed, some of them present a certain degree of cellular compartmentalization, even if some aspects of the subject are still under debate (Lindsay et al. 2001; Fuerst and Sagulenko 2011; Devos 2014). In particular, cell compartmentalization has been proposed for some members of Verrucomicrobia, such as Prostechobacter dejongeii (Verrucomicrobiaceae) and Coraliomargarita akajimensis (Puniceicoccaceae) based on molecular and ultrastructural studies (Lee et al. 2009; Pinos et al. 2016). In those two bacteria, the presence of two different cellular compartments, delimited by an intracytoplasmic membrane, has been described. These two compartments were recognizable as a ribosome-free region, the paryphoplasma, and a region containing ribosomes and nucleoid, the pirellulosome. In this framework, some morphological traits of " $\mathrm{Ca}$. Pinguicoccus 
bioRxiv preprint doi: https://doi.org/10.1101/666461; this version posted June 11,2019 . The copyright holder for this preprint (which was not certified by peer review) is the author/funder, who has granted bioRxiv a license to display the preprint in perpetuity. It is made available under aCC-BY-NC-ND 4.0 International license.

supinus", such as membrane invaginations and folding, could be considered homologous to those observed in other Verrucomicrobia and PVC members in general, although our data, based solely on TEM observation, definitely do not provide clear evidence of cell compartmentalization. A possible future development could be the use of cryo-electron tomography (Medeiros et al. 2018).

Endosymbiont genome The genome of " $\mathrm{Ca}$. Pinguicoccus supinus" was found to be extremely small (163,218 Kbp), being, to our best knowledge, the fourth smallest bacterial genome sequenced to date (smallest being " $\mathrm{Ca}$. Nasuia deltocephalinicola": 112,031 bp) (Bennet and Moran 2013). The novel genome is highly reduced and lacks many genes, especially compared with the relative free living Verrucomicrobia (range 2.2 - 7.3 Mbp; Hou et al. 2008; Kotak et al. 2015) but also with other Verrucomicrobia symbionts, such as the ones belonging to the genus " $\mathrm{Ca}$.

Xiphinematobacter" ( $\sim 916 \mathrm{Kbp})$ (Brown et al. 2015). The tiniest genomes $(<500 \mathrm{~Kb})$ are found in putatively ancient mutualistic symbioses, where symbionts are beneficial to their hosts' metabolism and hosts have in turn evolved to support and control the symbiosis (McCutcheon and Moran 2012; Bennet and Moran 2013; Moran and Bennett 2014; Kobiałka et al. 2016). Such levels of coevolution often also imply phenomena of severe genome reduction, with gene loss and often a subsequent modification of the nucleotide base composition (Moran and Bennet 2014). This framework gives us some clues to try to understand the peculiar characteristic of the novel symbiont "Ca. Pinguicoccus supinus". All other symbionts with highly reduced genomes provide their hosts with nutrients that are absent in their diet. In those cases, the nutritional support role is clear, due to the fact that they retain some metabolic pathways for the biosynthesis of amino acids essential for their hosts (Wilson et al. 2010; for a review see Moran and Bennet 2014). Moreover, several of these symbionts are co-obligate with other bacteria complementing each other for the enzymatic repertoire necessary to provide nutritional support to the host. This seems not to be the case of " $\mathrm{Ca}$. Pinguicoccus supinus", which is devoid of genes related to amino acids, co-factors or vitamins biosynthesis, and is the only symbiont retrieved in the E. vanleeuwenhoeki holobiont. The extensive gene loss and genome modification suggest that this symbiosis may have an ancient origin, and that it may play an important role for the host, although its function is yet to be understood. This case could be partly similar to that of the well-ascertained mutualist bacterium, Polynucleobacter necessarius in other Euplotes spp.. Indeed, this bacterium is necessary for the survival of its hosts, but no precise clues on the metabolic nature of the interaction have been provided by genomic analyses (Boscaro et al. 2013c, 2018). This has been linked to the peculiar ecology of ciliates, which normally feed on free-living bacteria, and are thus unlikely to require dietary compensations from bacterial endosymbionts. It has been hypothesized that they may require help in catabolism or other undefined functions, and such a contribution would not be simple to detect by analyses of the symbionts' genomes only (Boscaro et al. 2013c).

The comparison between " $\mathrm{Ca}$. Pinguicoccus supinus" and the other symbionts with highly reduced genomes shows the presence of a core set of 33 genes retained by all these evolutionary unrelated bacteria. Those genes are mostly involved in DNA replication, transcription, and translation, as well as in protein folding and stability. Clearly, these core cellular functions are required even in bacteria with such extremely reduced genomes. Interestingly, in " $\mathrm{Ca}$. Pinguicoccus supinus", it was not possible to find a gene homologous to DNA polymerase II catalytic subunit (dnaE), or, in general, to any other protein with predicted DNA polymerase catalytic activity. This is a striking difference with respect to the other analysed symbionts, and, to our best knowledge, it is a unique case among 
bioRxiv preprint doi: https://doi.org/10.1101/666461; this version posted June 11,2019 . The copyright holder for this preprint (which was not certified by peer review) is the author/funder, who has granted bioRxiv a license to display the preprint in perpetuity. It is made available under aCC-BY-NC-ND 4.0 International license.

all bacteria. A Blast analysis on the entire preliminary assembly of the whole holobiont did not reveal the presence of any $d n a E$ gene, suggesting that there is no such gene integrated in the host genome. This finding strongly suggests that " $\mathrm{Ca}$. Pinguicoccus supinus" relies on proteins obtained from the host to replicate its own genome, analogously to what has been proposed for other essential cellular functions for other symbionts with highly reduced genomes (Moran and Bennet 2014).

A common feature of the previously characterized symbiotic bacteria with highly reduced genomes is the complete lack of genes related to the production of components of the cellular envelope such as phospholipids, lipopolysaccharide, peptidoglycan and related membrane proteins (Moran and Bennett 2014). Unique in this regard, " $C a$. Pinguicoccus supinus" presents the pathway for the initiation and elongation of fatty acids, and several glycosyl transferases, although the phospholipid synthesis pathway is missing. Obligate small genome symbionts of insects are found in specialized cells, the bacteriocytes and some symbionts of unicellular eukaryotes are located in a specific cellular structure, the symbiosome, while " $\mathrm{Ca}$. Pinguicoccus supinus" resides free in the host cytoplasm. This could imply the requirement for a more complex regulation of the membrane structure (e.g. variation of fatty acids length in phospholipids) to face a "less stable" environment, thus possibly explaining the unique genes found in the genome of " $\mathrm{Ca}$. Pinguicoccus supinus". Interestingly, " $C a$. Pinguicoccus supinus" has often been observed in close contact with host's lipid droplets. This not yet elucidated interaction with host's lipids could be another reason for the retaining of genes devoted to fatty acid biosynthesis.

The genome of " $\mathrm{Ca}$. Pinguicoccus supinus" presents a non-standard genetic code (NCBI genetic code "4"), in which the canonical stop triplet UGA is recoded for tryptophan, consistently with the absence of release factor 2, implied in the normal recognition of UGA as stop. This is consistent with other highly reduced genomes (McCutcheon et al. 2009) and has been tentatively linked to a directional mutation pressure related to the AT/GC composition (Osawa and Jukes 1988), or directly linked to genome reduction and energetic constrains (McCutcheon et al. 2009).

Endosymbiont phylogeny Both the phylogenetic and phylogenomic analyses, the first including more taxa and the second more genes, support the position of " $C a$. Pinguicoccus supinus" in the family Puniceicoccaceae (Opitutae, Verrucomicrobia). We suggest that the long branch of the novel species is due to an overall high evolutionary rate, and consequently may decrease support for some nodes inside the family-clade.

It is worth to notice that our phylogenetic and phylogenomic analyses are among of the most taxonomically exhaustive up to date among Verrucomicrobia and resulted coherent with those from previous studies (Yoon et al. 2010; Yoon 2011; Kim et al. 2015; Parks et al. 2018). They also highlight the necessity of systematic revision for some species and taxa (i.e. Brevifollis gellanilyticus clustering within genus Prosthecobacter; Subdivision 3 and Subdivision 6 still waiting for a proper naming).

Endosymbiont diversity and environmental distribution In order to evaluate how widespread and abundant the novel taxon is, we evaluated the presence of sequences related to 16S rRNA gene of E. vanleeuwenhoeki endosymbiont in IMNGS, which resulted to be very limited. The main possible reason of the scarce abundance of " $\mathrm{Ca}$. Pinguicoccus supinus" and related sequences in online 
bioRxiv preprint doi: https://doi.org/10.1101/666461; this version posted June 11,2019 . The copyright holder for this preprint (which was not certified by peer review) is the author/funder, who has granted bioRxiv a license to display the preprint in perpetuity. It is made available under aCC-BY-NC-ND 4.0 International license.

repositories resides in the fact that $16 \mathrm{~S}$ rRNA gene primers employed in metabarcoding and metagenomic studies often do not detect certain bacterial groups, such as Verrucomicrobia (Bergmann et al. 2011; Takahashi et al. 2014). Indeed, the choice of primers used in such NGS analysis should be carefully pondered as some bacterial taxa might be undetected, thus not depicting the real diversity in an environment. Our analysis shows that the 16S rRNA sequences related to the endosymbiont were present in just $0.01 \%$ of total samples, and never reached $1 \%$ abundance in positive samples, a number of which resulted to be microbiome studies of multicellular organisms (Supplementary Table 9). The hypervariable region diversity analysis confirmed the limited presence of sequences from these bacteria sequence in metabarcoding samples. Extracting from the databases sequences similar to " $\mathrm{Ca}$. Pinguicoccus supinus" and performing phylogenies on the hypervariable regions of the 16S rRNA gene, six diverse groups could be identified, and their phylogenetic relationships retraced those of the complete 16S rRNA gene phylogeny (Figs 7, 10). Moreover, hypervariable region diversity analysis pointed out that "Ca. Pinguicoccus supinus" was usually a stand-alone sequence within its group, with the only exception of V4-V6 phylogenetic tree having a single OTU associated to the endosymbiont sequence (Fig. 10). On the contrary, the other related Puniceicoccaceae, which were isolated and characterized from the environment (mostly marine), clustered in groups encompassing numerous OTUs (Fig. 10). The same stand-alone phenomenon occurred also for the epixenosomes, the aforementioned ectosymbionts of the ciliate Euploditium arenarium, that always formed a defined and separated lineage in all our analyses (Fig. 10). The limited presence of OTUs associated to these microorganisms could be also explained with the symbiotic nature of these bacteria, which occupy a peculiar and circumscribed ecological niche, possibly making their detection more complicated. It is also worth to notice that the number of OTUs per clade is significantly different when region V1-V2 is compared to region V4-V6 (Fig. 10). Indeed, in region V1-V2 “ $C a$. Pinguicoccus supinus" and related clades (in red) are relatively richer in OTUs if compared to region V4-V6, whereas the opposite is true for the Coraliomargarita-"Fucophilus"-Puniceicoccus clade (in green). This observation suggests that commonly used primers for region V1-V2 and V4V6 could recognize the two clades with a different efficiency, producing artefactual results in terms of abundance and biodiversity.

\section{The holobiont paradigm as a possible new standard for the "next generation taxonomy" of unicellular organisms}

The concept that "host plus symbionts" constitute a single functional unit, with its own characteristics, different from and new with respect to those of the specific parts, is nowadays accepted by many researchers, albeit with different interpretations (Rosenberg et al. 2007; Bordenstein and Theis 2015; Bosch and Miller 2016; Roughgarden et al. 2018).

Therefore, to our opinion, it seems opportune, if not even necessary, to treat the sum of the different parts of this system in a unitary and integrated way, starting from the very beginning, i.e. the taxonomic description. Hence, we propose the idea of shifting attention of taxonomy from unicellular host and/or single symbionts to the whole holobiont. This approach integrates all the associated species characterizations into the holobiont description, providing not only morphological characters and molecular markers, but also functional and associative parameters. 
bioRxiv preprint doi: https://doi.org/10.1101/666461; this version posted June 11,2019 . The copyright holder for this preprint (which was not certified by peer review) is the author/funder, who has granted bioRxiv a license to display the preprint in perpetuity. It is made available under aCC-BY-NC-ND 4.0 International license.

According to this line of thought, such a multidisciplinary approach represents a considerable improvement, allowed by the development of more sophisticated and powerful tools in molecular biology and genomics. In details, here we suggest the inclusion of two additional descriptive parameters: the host's mitogenome and the characterization of the possibly present associated bionts, integrating novel useful features to the description of organisms. This does not imply that the traditional taxonomic tools are to be considered obsolete, and they will indeed continue to be the basis for species descriptions.

A question naturally arising is what should be considered a "holobiont". The system constituted by the unicellular host plus its bacterial symbiont(s) perfectly fits with the definition of "holobiont". As we pointed out earlier in the Introduction section, we suggest treating as a single holobiont the compound of different organisms in stable associations, which we can consider to be forming a single integrated functional and ecological unit. These systems fit the definition of symbiosis sensu de Bary, i.e. including parasitism. Indeed, in studies on symbiosis, a long lasting, yet unresolved, debate is how to define the boundaries among different kinds of symbiosis (e.g. ranging from mutualism to parasitism) (Goff 1982; Martin and Schwab 2012). The threshold could be particularly blurred for interactions between protists and other unicellular organisms. In practice, this "gray area" in between is frequently due to the difficulty to asses if symbionts of protists should be considered beneficial, neutral or detrimental for the host (Gast et al. 2009; Bernhard et al. 2018). Moreover, in some cases, the effect of the associated organism(s), whenever determined, has been observed to shift among the two poles, mutualism and parasitism, depending on several factors (e.g. host health, environmental changes, etc.) (Kusch et al. 2002; Hori and Fujishima 2003). Thus, considering all this theoretical and practical aspects, it seems appropriate to include also parasitism while defining the holobiont boundaries for taxonomic description of protists.

Last but not least, in case of protists the characterization of a host and its holobiome can be considered, in general, rather feasible in practice. Indeed, microorganisms associated with protists are usually few and, consequently, not so dramatically difficult to characterize, or at least, to detect. Moreover, obtaining protists' mitogenomes is relatively straightforward, given the relative low complexity that is generally associated to the nuclear genome of protists (Lynch 2005; Gregory 2005; Haygood 2006), thus allowing to limit sequencing and analysis efforts.

The case study here proposed is fully representative. In the newly described ciliate species, $E$. vanleeuwenhoeki sp. nov., a sole, stably associated bacterium was detected, namely the endosymbiont " $\mathrm{Ca}$. Pinguicoccus supinus", which makes the application of the holobiont concept to species description unambiguous. As detailed above, the peculiar features of this symbiont, especially the genomic ones, are strongly indicative of a long coevolutionary and adaptation history with its host, so that this bacterium could be even hypothesized as an autoapomorphic character for the host species. Thus, this symbiotic system unambiguously fits the holobiont definition herein proposed for taxonomic purposes (highly integrated system with emerging properties).

In conclusion, in our view, the "next generation taxonomy" approach can constitute a new and valuable standard for unicellular eukaryotes descriptions and redescriptions. Indeed, integrating standard taxonomical analyses with the most modern tools in genomics and bioinformatics and the concept of holobiont, it provides additional descriptors valuable not only to fully and unambiguously define a species but also to infer its interaction with other organisms and, at least 
bioRxiv preprint doi: https://doi.org/10.1101/666461; this version posted June 11, 2019. The copyright holder for this preprint (which was not certified by peer review) is the author/funder, who has granted bioRxiv a license to display the preprint in perpetuity. It is made available under aCC-BY-NC-ND 4.0 International license.

partially, its biology. At practical level, the suitability of the proposed approach for unicellular eukaryotic organisms, in particular free-living forms, associated with bacterial endobionts, is herein documented with the description of E. vanleeuwenhoeki, and we are rather confident that it should be similarly straightforward if applied to other kinds of holobiontic protists.

\section{Applicability of the "next generation taxonomy" to "higher-level" organisms}

The hardest challenge for the "next generation taxonomy" is, for sure, to become suitable for "higher-level” organisms' description/redescription. In this task there are, indeed, several issues. First of all, in general, there are some difficulties in defining which organisms may constitute a holobiont among multicellular and compartimentalized organisms such as metazoa (e.g. humans and associated gut microbiota), and therefore to determine if an associated organism should be included as an additional descriptor. Moreover, in this regard, the characteristics of the microbiota are also rather different in different types of organisms. In vertebrates, including humans, variations in the composition of the "holobiont", even just focussing on the gut microbiota, are enormous. Microbiota composition varies during post-birth development, is profoundly influenced by the diet, and by a variety of environmental and genetic factors (Huse et al. 2012). Even a precise description of the core gut microbiota is problematic, and the focus is more toward the description of the core microbiome (Lloyd-Price et al. 2016). The scenario is similar in many arthropods, in particular in insects, where the composition of the microbial communities associated with the different body districts is highly variable (see for example Montagna et al. 2015; Montagna et al. 2016), with core microbiotas easily defined only in some taxa (e.g. in termites), or for some types of symbiotic associations (e.g. in the presence of vertically transmitted primary symbionts). Thus, while in dealing with well defined obligate/stable symbionts of insects (e.g. Buchnera aphidicola, " $\mathrm{Ca}$. Zinderia insecticola", etc.), the application of the holobiont concept to taxon description could be straightforward, it does not come easy when focussing on highly variable microbial communities. In any case, from a purely practical perspective, it would be not be feasible or even at all possible for researchers to identify and list all the possible associated microorganisms of the metazoans' microbiota. Moreover, also the host's mitogenome analysis could be not so straightforward, compared to unicellular organisms, given the size and the higher complexity of the nuclear genome of most metazoans (Lynch 2005; Gregory 2005; Haygood 2006). Even with the most modern sequencing and bioinformatic techniques available, this task could become too challenging and time-demanding for taxonomists.

In other words, from both a conceptual (i.e. how to apply the holobiont definition) and a practical (i.e. mitogenome and microbiome analyses) point of view, in our opinion, the present state of the art and technology do not allow to apply the "next generation taxonomy" approach to multicellular organisms.

To sum up, we consider the proposed workflow, which we named "next generation taxonomy", extremely valuable and practicable for unicellular eukaryotic organisms, and we encourage the inclusion in their descriptions of mitogenome and associated bionts. On the other side, for multicellular organisms we consider this approach to be still premature, although attempts on more anatomically simple organisms (e.g. Placozoa (Driscoll et al. 2013), Orthonectida (Bondarenko et al. 2019)), with presumably lower complexity microbiomes, could be tempting. 


\section{Nomenclature acts}

The present work has been registered in ZooBank (code:

LSID:urn:1sid:zoobank.org:pub:231DF703-DBA8-4839-9755-5C71D6872406), as well as the new Euplotes species, Euplotes vanleeuwenhoeki (code: LSID:urn:lsid:zoobank.org:act:19C2249BBF2D-4E81-9391-A271D38CD7B6). The correspondent web pages are available at the following addresses: http://www.zoobank.org/References/231DF703-DBA8-4839-9755-5C71D6872406 and http://www.zoobank.org/NomenclaturalActs/19C2249B-BF2D-4E81-9391-A271D38CD7B6 , respectively.

\section{Description of "Candidatus Pinguicoccus" gen. nov.}

Pinguicoccus [Pin.gui.coc'cus. L. adj. pinguis fat; N.L. n. coccus (from Gr. masc. n. kokkos grain, seed) coccus: N.L. masc. n. Pinguicoccus, a fat coccus, because its rounded body shape and because it was often found associated with host's lipid droplets].

The genus description at present is the same as the description of the type species " $\mathrm{Ca}$. Pinguicoccus supinus".

\section{Description of "Candidatus Pinguicoccus supinus" sp. nov.}

Pinguicoccus supinus (su.pi'nus. L. adj. supinus lying on the back, supine, indolent, lazy, because it is not a motile microorganism and because it lacks several fundamental metabolic pathways).

Type species of the genus. Non motile Verrucomicrobia bacterium of family Puniceicoccaceae (class Opitutae). Roundish-ovoid in shape, detected in the cytoplasm of the ciliate Euplotes vanleeuwenhoeki, with a diameter of 1.3-2.3 $\mu \mathrm{m}$. It usually lies beneath the ciliate cortex, often in clusters of several individuals. Cells are delimited by a double membrane with a thin space between the two layers; no symbiosome was ever observed. In several individuals, an invagination of the inner membrane and folding of the outer membrane are observed. Homogeneous bacterial cytoplasm. Sometimes shows presence of nucleoids. Reproduce by binary fission in the host cytoplasm, by means of an apparently typical symmetrical division. Its genome size is $163,218 \mathrm{bp}$ and $\mathrm{G}+\mathrm{C}$ content is $25 \%$. The genetic code for protein translation is the "translation table 4 ".

Base of attribution: 16S rRNA gene sequence, MK569697; complete genome sequence CP039370; recognized by oligonucleotidic probes EUB338 VII and Pingui_1174.

\section{Acknowledgements}

The authors are grateful to the Marine Biology Laboratory, Andhra University, India, for providing the research facilities. In particular, Professor Kalavati, Professor Raman Akkur, and Professor Prabhakara Rao Yallapragada are acknowledged for their valuable aid. Special acknowledgements to Simone Gabrielli for tree and photo-editing support. This work was supported by the European Commission FP7-PEOPLE-2009-IRSES project CINAR PATHOBACTER (247658) (to GP); the 
University of Pisa PRA_2018_63 project (to GP); the Italian Ministry of Education, University and Research (MIUR): Dipartimenti di Eccellenza Program (2018-2022) - Dept. of Biology and Biotechnology "L. Spallanzani", University of Pavia (to DS).

\section{Author Contributions}

Conceptualization: GP, VS, LG

Sampling and culturing: VN, BVS

Morphological and ultrastructural analyses: VN, LM

Molecular analyses: VS, LG, VN

Bioinformatics: LG, MC, DS

Phylogeny and phylogenomic analyses: VS, LG, MC, GP

Environmental screening on IMNGS: OL

Visualization: VN, VS, LG, LM, OL, FV, GP

Funding acquisition: GP, FV, DS, CB

Work supervision: GP, LM

Writing - original draft: VS, LG, LM, OL

Writing - review \& editing: GP, MC, DS, CB, VN, FV, BVS

\section{References}

Agnarsson I., Kuntner M. 2007. Taxonomy in a changing world: seeking solutions for a science in crisis. Syst. Biol. 56:531-539.

Al-Jassim N., Ansari M.I., Harb M., Hong P.Y. 2015. Removal of bacterial contaminants and antibiotic resistance genes by conventional wastewater treatment processes in Saudi Arabia: is the treated wastewater safe to reuse for agricultural irrigation? Water Res. 73:277-290.

Amann R.I., Binder B.J., Olson R.J., Chisholm S.W., Devereux R., Stahl D.A. 1990. Combination of 16S rRNA-targeted oligonucleotide probes with flow cytometry for analyzing mixed microbial populations. Appl. Environ. Microbiol. 56:1919-1925.

Bankevich A., Nurk S., Antipov D., Gurevich A.A., Dvorkin M., Kulikov A.S., Lesin V.M., Nikolenko S.I., Pham S., Prjibelski A.D., Pyshkin A.V., Sirotkin A.V., Vyahhi N., Tesler G., Alekseyev M.A., Pevzner P.A. 2012. SPAdes: a new genome assembly algorithm and its applications to single-cell sequencing. J. Bioinform. Comput. Biol. 19:455-477. doi:10.1089/cmb.2012.0021.

Barth D., Krenek S., Fokin S.I., Berendonk T.U. 2006. Intraspecific genetic variation in Paramecium revealed by mitochondrial cytochrome c oxidase I sequences. J. Eukaryot. Microbiol. 50:20-25. 
de Bary A. 1879. Die Erscheinung der Symbiose. Strassburg: Verlag von Karl J. Trübner.

Bella C., Koehler L., Grosser K., Berendonk T.U., Petroni G., Schrallhammer M. 2016. Fitness impact of obligate intranuclear bacterial symbionts depends on host growth phase. Front. Microbiol. 2084.

Bennett G.M., Abbà S., Kube M., Marzachì C. 2016. Complete genome sequences of the obligate symbionts "Candidatus Sulcia muelleri" and "Ca. Nasuia deltocephalinicola" from the pestiferous Leafhopper Macrosteles quadripunctulatus (Hemiptera: Cicadellidae). Genome Announc. 4:e01604-15.

Bennett G.M., Moran N.A. 2013. Small, smaller, smallest: the origins and evolution of ancient dual symbioses in a phloem-feeding insect. Genome Biol. Evol. 5:1675-1688.

Berger H. 2006. Monograph of the Urostyloidea (Ciliophora, Hypotricha). Monogr. Biol. 85:11303.

Bergmann G.T., Bates S.T., Eilers K.G., Lauber C.L., Caporaso J.G., Walters W.A., Knight R., Fierer N. 2011. The under-recognized dominance of Verrucomicrobia in soil bacterial communities. Soil. Biol. Biochem. 43:1450-1455.

Bergsten J. 2005. A review of long-branch attraction. Cladistics. 21:163-193.

Berlanga M., Guerrero R. 2016. The holobiont concept: the case of xylophagous termites and cockroaches. Symbiosis. 68:49-60.

Bernhard J.M., Tsuchiya M., Nomaki H. 2018. Ultrastructural observations on prokaryotic associates of benthic foraminifera: Food, mutualistic symbionts, or parasites? Mar. Micropaleontol. 138:33-45.

Blanchette M., Kunisawa T., Sankoff D. 1996. Parametric genome rearrangement. Gene. 172:GC11-GC17.

Bondarenko, N., Bondarenko, A., Starunov, V., Slyusarev, G. 2019. Comparative analysis of the mitochondrial genomes of Orthonectida: insights into the evolution of an invertebrate parasite species. Mol. Genet. Genomic. 1-13.

Boore J.L., Brown W.M. 1998. Big trees from little genomes: mitochondrial gene order as a phylogenetic tool. Curr. Opin. Genet. Dev. 8:668-674.

Bordenstein S.R., Theis K.R. 2015. Host biology in light of the microbiome: ten principles of holobionts and hologenomes. PLoS Biol. 13:e1002226.

Boscaro V., Felletti M., Vannini C., Ackerman M.S., Chain P.S., Malfatti S., Vergez L.M., Shin M., Doak T.G., Lynch M., Petroni G. 2013c. Polynucleobacter necessarius, a model for genome reduction in both free-living and symbiotic bacteria. Proc. Natl. Acad. Sci. USA. 110:18590-18595.

Boscaro V., Fokin S.I., Schrallhammer M., Schweikert M., Petroni G. 2013a. Revised systematics of Holospora-like bacteria and characterization of "Candidatus Gortzia infectiva", a novel macronuclear symbiont of Paramecium jenningsi. Microb. Ecol. 65:255-267. 
bioRxiv preprint doi: https://doi.org/10.1101/666461; this version posted June 11,2019 . The copyright holder for this preprint (which was not certified by peer review) is the author/funder, who has granted bioRxiv a license to display the preprint in perpetuity. It is made available under aCC-BY-NC-ND 4.0 International license.

Boscaro V., Kolisko M., Felletti M., Vannini C., Lynn D.H., Keeling P.J. 2018. Parallel genome reduction in symbionts descended from closely related free-living bacteria. Nature Ecol. Evol. $1: 1160$.

Boscaro V., Petroni G., Ristori A., Verni F., Vannini C. 2013b. “Candidatus Defluviella procrastinata" and "Candidatus Cyrtobacter zanobii", two novel ciliate endosymbionts belonging to the "Midichloria clade. Microb. Ecol. 65:302-310.

Boscaro V., Syberg-Olsen M.J., Irwin N.A., del Campo J., Keeling P.J. 2019. What can environmental sequences tell us about the distribution of low-rank taxa? The case of Euplotes (Ciliophora, Spirotrichea), including a description of Euplotes enigma sp. nov. J. Euk. Microbiol. 66:281-293. https://doi.org/10.1111/jeu.12669.

Boscaro V., Vannini C., Fokin S.I., Verni F., Petroni G. 2012. Characterization of "Candidatus Nebulobacter yamunensis" from the cytoplasm of Euplotes aediculatus (Ciliophora, Spirotrichea) and emended description of the family Francisellaceae. Syst. Appl. Microbiol. 35:432-440.

Bosch T.C., Miller D.J. 2016. The holobiont imperative: perspectives from early emerging animals. Springer, Vienna.

Brown A.M., Howe D.K., Wasala S.K., Peetz A.B., Zasada I.A., Denver D.R. 2015. Comparative genomics of a plant-parasitic nematode endosymbiont suggest a role in nutritional symbiosis. Genome Biol. Evol. 7:2727-2746.

Burger G., Zhu Y., Littlejohn T.G., Greenwood S.J., Schnare M.N., Lang B.F., Gray, M.W. 2000. Complete sequence of the mitochondrial genome of Tetrahymena pyriformis and comparison with Paramecium aurelia mitochondrial DNA1. J. Mol. Biol. 297:365-380.

Cameron S.L. 2014. Insect mitochondrial genomics: implications for evolution and phylogeny. Annu. Rev. Entomol. 59:95-117.

Carter H.P. 1972. Infraciliature of eleven species of the genus Euplotes. Trans. Am. Microsc. Soc. 466-492.

Casiraghi M. 2012. Being an individual (or a species) in a symbiotic world. Paradigmi. 3:59-69.

Castelli M., Serra V., Senra M.V., Basuri C.K., Soares C.A.G., Fokin S.I., Modeo L., Petroni G. 2019. The hidden world of Rickettsiales symbionts: "Candidatus Spectririckettsia obscura," a novel bacterium found in Brazilian and Indian Paramecium caudatum. Microb. Ecol. 1-11. https://doi.org/10.1007/s00248-018-1243-8.

Chiellini C., Pasqualetti C., Lanzoni O., Fagorzi C., Bazzocchi C., Fani R., Petroni G., Modeo L. 2019. Harmful effect of Rheinheimera sp. EpRS3 (Gammaproteobacteria) against the protist Euplotes aediculatus (Ciliophora, Spirotrichea): insights into the ecological role of antimicrobial compounds from environmental bacterial strains. Front. Microbiol. 10:510. doi:

10.3389/fmicb.2019.00510.

Cole J.R., Wang Q., Cardenas E., Fish J., Chai B., Farris R.J., Kulam-Syed-Mohideen A.S., McGarrell D. M., Marsh T., Garrity G.M., Tiedje J. M. 2009. The ribosomal database project: improved alignments and new tools for rRNA analysis. Nucleic. Acids. Res. 37: D141-D145. doi: 10.1093/nar/gkn879 
Collins A.J., LaBarre B.A., Won B.S.W., Shah M.V., Heng S., Choudhury M.H., Haydar S.A., Santiago J., Nyholm S.V. 2012. Diversity and partitioning of bacterial populations within the accessory nidamental gland of the squid Euprymna scolopes. Appl. Environ. Microbiol. AEM07437.

Corliss J.O. 1953. Silver impregnation of ciliated protozoa by the Chatton-Lwoff technic. Stain Technology. 28:97-100.

Curds C.R. 1975. A guide to the species of the genus Euplotes (Hypotrichida, Ciliatea). Bull. Br. Mus. (Nat. Hist.) Zool. 28:1-61.

Daims H., Brühl A., Amann R., Schleifer K.H., Wagner M. 1999. The domain-specific probe EUB338 is insufficient for the detection of all Bacteria: development and evaluation of a more comprehensive probe set. Syst. Appl. Microbiol. 22:434-444.

Darriba D., Taboada G.L., Doallo R., Posada D. 2011. ProtTest 3: fast selection of best-fit models of protein evolution. Bioinformatics 27:1164-1165.

Darriba D., Taboada G.L., Doallo R., Posada D. 2012. jModelTest 2: more models, new heuristics and parallel computing. Nat. Methods. 9:772. https://doi.org/10.1038/nmeth.2109.

Devos D.P. 2014. PVC bacteria: variation of, but not exception to, the Gram-negative cell plan. Trends Microbiol. 22:14-20.

Diller W.F., Kounaris D. 1966. Description of a zoochlorella-bearing form of Euplotes, E. daidaleos n. sp.(Ciliophora Hypotrichida). Biol. Bull. 131:437-445.

Doerder F.P. 2019. Barcodes Reveal 48 New Species of Tetrahymena, Dexiostoma, and Glaucoma: phylogeny, ecology, and biogeography of new and established species. J. Eukaryot. Microbiol. 66:182-208.

Douglas A.E., Werren J.H. 2016. Holes in the hologenome: why host-microbe symbioses are not holobionts. mBio 7:e02099-15

Dragesco J., Dragesco-Kernéis A. 1986. Ciliés libres de 1' Afrique Intertropicale. Introduction á la connaissance et á l'étude des ciliés. Faune tropicale. In L'Orstom ed., Paris 26:1-559.

Driscoll T., Gillespie J.J., Nordberg E.K., Azad A.F., Sobral B.W. 2013. Bacterial DNA sifted from the Trichoplax adhaerens (Animalia: Placozoa) genome project reveals a putative rickettsial endosymbiont. Genome Biol. Evol. 5:621-645.

Dumilag R.V., Gallardo W.G.M., Garcia C.P.C., You Y., Chaves A.K.G., Agahan L. 2018. Phenotypic and mtDNA variation in Philippine Kappaphycus cottonii (Gigartinales, Rhodophyta). Mitochondrial DNA. 29:951-963.

Edgar R.C. 2004. MUSCLE: multiple sequence alignment with high accuracy and high throughput. Nucleic Acids Res. 32:1792-1797.

Edgar R.C. 2010. Search and clustering orders of magnitude faster than BLAST. Bioinformatics 26:2460-2461.

Egan S., Harder T., Burke C., Steinberg P., Kjelleberg S., Thomas T. 2012. The seaweed holobiont: understanding seaweed-bacteria interactions. FEMS Microbiol. Rev. 37:462-476. 
Emms D.M., Kelly S. 2015. OrthoFinder: solving fundamental biases in whole genome comparisons dramatically improves orthogroup inference accuracy. Genome Biol. 16:157.

Faure'-Fremiet E., Andre' J. 1968. Structure fine de l' Euplotes eurystomus (WRZ). Arch. Anat. Micro. Morph. Ex. 57:53-78.

Fenchel T., Lee C.C. 1972. Studies on ciliates associated with sea ice from Antarctica. I. The nature of the fauna. Arch. Protistenk 114:231-236.

Ferrantini F., Fokin S.I., Modeo L., Andreoli I., Dini F., Görtz, H.-D., Verni F., Petroni, G. 2009. "Candidatus Cryptoprodotis polytropus," a novel Rickettsia-like organism in the ciliated protist Pseudomicrothorax dubius (Ciliophora, Nassophorea). J. Eukaryot. Microbiol. 56:119-129.

Ferreira T., Rasband W. 2012. ImageJ user guide. ImageJ/Fiji, 1. (https://imagej.nih.gov/ij/docs/guide/user-guide.pdf).

Finlay B.J., Berninger U.G., Stewart L.J., Hindle R.M., Davison W. 1987. Some factors controlling the distribution of two pond-dwelling ciliates with algal symbionts (Frontonia vernalis and Euplotes daidaleos). J. Protozool. 34:349-356.

Foissner W. 2006. Biogeography and dispersal of micro-organisms: a review emphasizing protists. Acta Protozool. 45:111-136.

Fokin S.I., Di Giuseppe G., Erra F., Dini F. 2008. Euplotespora binucleata n. gen., n. sp.(Protozoa: Microsporidia), a parasite infecting the hypotrichous ciliate Euplotes woodruffi, with observations on microsporidian infections in Ciliophora. J. Eukaryot. Microbiol. 55:214-228.

Fokin S.I., Schrallhammer M., Chiellini C., Verni F., Petroni G. 2014. Free-living ciliates as potential reservoirs for eukaryotic parasites: occurrence of a trypanosomatid in the macronucleus of Euplotes encysticus. Parasite. Vector. 7:203.

Fokin S.I., Serra V., Ferrantini F., Modeo L., Petroni G. 2019. “Candidatus Hafkinia simulans” gen. nov., sp. nov., a novel Holospora-like bacterium from the macronucleus of the rare brackish water ciliate Frontonia salmastra (Oligohymenophorea, Ciliophora): multidisciplinary characterization of the new endosymbiont and its host. Microb. Ecol.1-15. https://doi.org/10.1007/s00248-018-1311-0.

Freitas S., Hatosy S., Fuhrman J.A., Huse S.M., Welch D.B.M., Sogin M.L., Martiny A.C. 2012. Global distribution and diversity of marine Verrucomicrobia. ISME J. 6:1499.

Fuerst J.A., Sagulenko E. 2011. Beyond the bacterium: planctomycetes challenge our concepts of microbial structure and function. Nat. Rev. Microbiol. 6:403.

Galperin M.Y., Kristensen D.M., Makarova K.S., Wolf Y.I., Koonin E.V. 2017. Microbial genome analysis: the COG approach. Brief Bioinf. 10.1093/bib/bbx117.

Gast R.J., Sanders R.W., Caron DA. 2009. Ecological strategies of protists and their symbiotic relationships with prokaryotic microbes. Trends Microbiol. 17:563-569.

Giambelluca M.A., Rosati G. 1996. Behavior of epixenosomes and the epixenosomal band during divisional morphogenesis in Euplotidium itoi (Ciliata, Hypotrichida). Eur. J. Protistol. 32:77-80. 
bioRxiv preprint doi: https://doi.org/10.1101/666461; this version posted June 11,2019 . The copyright holder for this preprint (which was not certified by peer review) is the author/funder, who has granted bioRxiv a license to display the preprint in perpetuity. It is made available under aCC-BY-NC-ND 4.0 International license.

Gilbert S.F., McDonald E., Boyle N., Buttino N., Gyi L., Mai M., Prakash N., Robinson J., 2010. Symbiosis as a source of selectable epigenetic variation: taking the heat for the big guy. Philos. T. Roy. Soc. B 365:671-678.

Gilbert S.F., Bosch T.C.G., Ledón-Rettig C., 2015. Eco-Evo-Devo: developmental symbiosis and developmental plasticity as evolutionary agents. Nat. Rev. Genet. 16:611, doi:10.1038/nrg3982.

Goff L.J. 1982. Symbiosis and parasitism: another viewpoint. BioScience 32:255-256.

Görtz H.-D. 2010. Microbial infections in free-living protozoa. Crit. Rev. Immunol. 30(1).

Gong J., Qing Y., Guo X., Warren A. 2014. “Candidatus Sonnebornia yantaiensis”, a member of candidate division OD1, as intracellular bacteria of the ciliated protist Paramecium bursaria (Ciliophora, Oligohymenophorea). Syst. Appl. Microbiol. 37:35-41.

de Graaf R.M., van Alen T.A., Dutilh B.E., Kuiper J.W., van Zoggel H.J., Huynh M.B., Görtz H.D., Huynen M.A., Hackstein J.H. 2009. The mitochondrial genomes of the ciliates Euplotes minuta and Euplotes crassus. BMC Genomics 10:514. doi:10.1186/1471-2164-10-514.

Graham L.E., Graham J.M. 1980. Endosymbiotic Chlorella (Chlorophyta) in a species of Vorticella (Ciliophora). T. Am. Microsc. Soc. 160-166.

Gregory T.R. 2005. Synergy between sequence and size in large-scale genomics. Nat. Rev. Genet. 6:699.

Greuter D., Loy, A., Horn M., Rattei T. 2015. probeBase - an online resource for rRNA-targeted oligonucleotide probes and primers: new features 2016. Nucleic Acids Res. 44:D586-D589. doi:10.1093/nar/gkv1232.

Grosser K., Ramasamy P., Amirabad A.D., Schulz M.H., Gasparoni G., Simon M., Schrallhammer M. 2018. More than the "killer trait": infection with the bacterial endosymbiont caedibacter taeniospiralis causes transcriptomic modulation in Paramecium host. Genome Biol. Evol. 10:646656.

Guerrero R., Margulis L., Berlanga M. 2013. Symbiogenesis: the holobiont as a unit of evolution. Int. Microbiol. 16:133-143.

Guindon S., Gascuel O. 2003. A simple, fast, and accurate algorithm to estimate large phylogenies by maximum likelihood. Syst. Biol. 52:696-704. https://doi.org/10.1080/10635150390235520.

Haygood R. 2006. Mutation rate and the cost of complexity. Mol. Biol. Evol. 23:957-963.

He M., Wang J., Fan X., Liu X., Shi W., Huang N., Zhao F., Miao M. 2019. Genetic basis for the establishment of endosymbiosis in Paramecium. ISME J. 1-10. https://doi.org/10.1038/s41396-0180341-4

Heckmann K., Hagen R.T., Görtz H.D. 1983. Freshwater Euplotes species with a 9 type 1 cirrus pattern depend upon endosymbionts. J. Protozool. 30:284-289.

Heckmann K., Schmidt H.J. 1987. Polynucleobacter necessarius gen. nov., sp. nov., an obligately endosymbiotic bacterium living in the cytoplasm of Euplotes aediculatus. Int. J. Sys.Evol. Microbiol. 37:456-457. 
bioRxiv preprint doi: https://doi.org/10.1101/666461; this version posted June 11 2019. The copyright holder for this preprint (which was not certified by peer review) is the author/funder, who has granted bioRxiv a license to display the preprint in perpetuity. It is made available under aCC-BY-NC-ND 4.0 International license.

Hester E.R., Barott K.L., Nulton J., Vermeij M.J., Rohwer F.L. 2016. Stable and sporadic symbiotic communities of coral and algal holobionts. ISME J. 10:1157-1169.

van Hoek A.H., van Alen T.A., Sprakel V.S., Leunissen J.A., Brigge T., Vogels G.D., Hackstein J.H. 2000. Multiple acquisition of methanogenic archaeal symbionts by anaerobic ciliates. Mol. Biol. Evol. 17:251-258.

Hori M., Fujishima M. 2003. The endosymbiotie bacterium Holospora obtusa enhances heat-shock gene expression of the host Paramecium caudatum. J. Eukaryot. Microbiol. 50:293-298.

Horn M. 2008. Chlamydiae as symbionts in eukaryotes. Annu. Rev. Microbiol. 62:113-131.

Hou S., Makarova K.S., Saw J.H., Senin P., Ly B.V., Zhou Z., Ren Y., Wang J., Galperin M.Y., Omelchenko M.V., Wolf Y.I., Ytin N., Koonin E.V., Stott M.W., Mountain B.W., Crowe M.A., Smirnova A.V., Dunfield P.F., Lu F., Wang L., Alam M. 2008. Complete genome sequence of the extremely acidophilic methanotroph isolate V4, Methylacidiphilum infernorum, a representative of the bacterial phylum Verrucomicrobia. Biol. Direct. 3: 26.

Huang J., Dunthorn M., Song W. 2012. Expanding character sampling for the molecular phylogeny of euplotid ciliates (Protozoa, Ciliophora) using three markers, with a focus on the family Uronychiidae. Mol. Phylogenetics Evol. 63:598-605.

Huse S.M., Ye Y., Zhou Y., Fodor A.A. 2012. A core human microbiome as viewed through $16 \mathrm{~S}$ rRNA sequence clusters. PLoS One 7:e34242. doi:10.1371/journal.pone.0034242.

Ilyasov R.A., Poskryakov A.V., Nikolenko A.G. 2016. Seven genes of mitochondrial genome enabling differentiation of honeybee subspecies Apis mellifera. Russ. J. Genet. 52:1062-1070.

Jiang J., Zhang Q., Warren A., Al-Rasheid K.A.S., Song W. 2010. Morphology and SSU rRNA gene-based phylogeny of two marine Euplotes species, E. orientalis spec. nov. and E. raikovi Agamaliev, 1966 (Ciliophora, Euplotida). Eur. J. Protistol. 46:121-132. doi:10.1016/j.ejop.2009.11.003 PMID:20172700

Katoh K., Misawa K., Kuma K.I., Miyata T. 2002. MAFFT: a novel method for rapid multiple sequence alignment based on fast Fourier transform. Nucleic Acids Res. 30:3059-3066.

Katoh K., Standley D.M. 2013. MAFFT multiple sequence alignment software version 7: improvements in performance and usability. Mol. Biol. Evol. 30:772-780.

Kim M., Pak S., Rim S., Ren L., Jiang F., Chang X., Zhang Y., Fang C., Zheng C., Peng F. 2015. Luteolibacter arcticus sp. nov., isolated from high Arctic tundra soil, and emended description of the genus Luteolibacter. Int. J. Syst. Evol. Microbiol. 65:1922-1928.

Kloetzel J.A. 1974. Feeding in ciliated Protozoa. Pharyngeal disks in Euplotes: a source of membrane for food vacuole formation. J. Cell. Sci. 15:379-401.

Kobiałka M., Michalik A., Walczak M., Junkiert Ł., Szklarzewicz, T. 2016. Sulcia symbiont of the leafhopper Macrosteles laevis (Ribaut, 1927) (Insecta, Hemiptera, Cicadellidae: Deltocephalinae) harbors Arsenophonus bacteria. Protoplasma 253:903-912. 
bioRxiv preprint doi: https://doi.org/10.1101/666461; this version posted June 11,2019 . The copyright holder for this preprint (which was not certified by peer review) is the author/funder, who has granted bioRxiv a license to display the preprint in perpetuity. It is made available under aCC-BY-NC-ND 4.0 International license.

Kodama Y., Fujishima M. 2012. Cell division and density of symbiotic Chlorella variabilis of the ciliate Paramecium bursaria is controlled by the host's nutritional conditions during early infection process. Environ. Microbiol. 14:2800-2811.

Kopp M., Tollrian R. 2003. Reciprocal phenotypic plasticity in a predator-prey system: inducible offences against inducible defences? Ecol. Lett. 6:742-748.

Kotak M., Isanapong J., Goodwin L., Bruce D., Chen A., Han C.S., Huntemann M., Ivanova N., Land M.L., Nolan M., Pati A., Woyke T., Rodrigues J.L.M. 2015. Complete genome sequence of the Opitutaceae bacterium strain TAV5, a potential facultative methylotroph of the wood-feeding termite Reticulitermes flavipes. Genome Announc. 3(2), e00060-15.

Kuhlmann H.-W., Heckmann K. 1994. Predation risk of typical ovoid and winged morphs of Euplotes (Protozoa, Ciliophora). Hydrobiologia 284:219-227.

Kumar S., Jones M., Koutsovoulos G., Clarke M., Blaxter M. 2013. Blobology: exploring raw genome data for contaminants, symbionts and parasites using taxon-annotated GC-coverage plots. Front. Genet. 4:237. doi:10.3389/fgene.2013.00237.

Kusch J., Czubatinski L., Nachname S., Hübner M., Alter M., Albrecht P. 2002. Competitive advantages of Caedibacter-infected paramecia. Protist 153:47-58.

Lagkouvardos I., Joseph D., Kapfhammer M., Giritli S., Horn M., Haller D., Clavel T. 2016. IMNGS: A comprehensive open resource of processed 16S rRNA microbial profiles for ecology and diversity studies. Sci. Rep. 6: 33721.

Lanzoni O., Fokin S.I., Lebedeva N., Migunova A., Petroni G., Potekhin A. 2016. Rare freshwater ciliate Paramecium chlorelligerum Kahl, 1935 and its macronuclear symbiotic bacterium “Candidatus Holospora parva”. PloS one 11(12), e0167928.

https://doi.org/10.1371/journal.pone.0167928

Lanzoni O., Sabaneyeva E., Modeo L., Castelli M., Lebedeva N., Verni F., Schrallhammer M., Potekhin A., Petroni G. 2019. Diversity and environmental distribution of the cosmopolitan endosymbiont “Candidatus Megaira”. Sci. Rep. doi:10.1038/s41598-018-37629-w.

Lavrov D.V., Brown W.M., Boore J.L. 2004. Phylogenetic position of the Pentastomida and (pan) crustacean relationships. Proc. R. Soc. Lond. B. Biol. Sci. 271:537-544.

Lee K.C., Webb R.I., Janssen P.H., Sangwan P., Romeo T., Staley J.T., Fuerst, J.A. 2009. Phylum Verrucomicrobia representatives share a compartmentalized cell plan with members of bacterial phylum Planctomycetes. BMC Microbiol. 9:5.

Li L., Song W. 2006. Phylogenetic position of the marine ciliate, Certesia quadrinucleata (Ciliophora; Hypotrichia; Hypotrichida) inferred from the complete small subunit ribosomal RNA gene sequence. Eur.J. Protistol. 42:55-61.

Lian C., Luo X., Fan X., Huang J., Yu Y., Bourland W., Song W. 2018. Morphological and molecular redefinition of Euplotes platystoma Dragesco \& Dragesco-Kernéis, 1986 and Aspidisca lynceus (Müller, 1773) Ehrenberg, 1859, with reconsideration of a "Well-known" Euplotes ciliate, Euplotes harpa Stein, 1859 (Ciliophora, Euplotida). J. Eukaryot. Microbiol. 65:531-543. 
Lindsay M.R., Webb R.I., Strous M., Jetten M.S., Butler M.K., Forde R.J., Fuerst, J.A. 2001. Cell compartmentalisation in planctomycetes: novel types of structural organisation for the bacterial cell. Arc. Microbiol. 175:413-429.

Lloyd-Price J., Abu-Ali G., Huttenhower C. 2016. The healthy human microbiome. Genome Med. 8:51. doi: 10.1186/s13073-016-0307-y.

Lobban C.S., Modeo L., Verni F., Rosati G. 2005. Euplotes uncinatus (Ciliophora, Hypotrichia), a new species with zooxanthellae. Mar. Biol. 147:1055-1061.

Lynch M. 2005. The origins of eukaryotic gene structure. Mol. Biol. Evol. 23:450-468.

Lynn D.H. 2008. The ciliated protozoa: characterization, classification, and guide to the literature. Springer Science and Business Media.

Mallet J., Willmott K. 2003. Taxonomy: renaissance or Tower of Babel? Trends Ecol. Evol. 18:5759.

Margulis L. 1991. Symbiogenesis and symbionticism. In: Margulis L., Fester R., editors. Symbiosis as a source of evolutionary innovation. MIT Press, Cambridge, pp. 1-14.

Martin B.D., Schwab E. 2012. Symbiosis:“Living together” in chaos. Stud. Hist. Biol. 4:7-25.

McCutcheon J.P., McDonald B.R., Moran N.A. 2009. Origin of an alternative genetic code in the extremely small and GC-rich genome of a bacterial symbiont. PLoS Genetics 5:1000565.

McCutcheon J.P., Moran, N.A. 2012. Extreme genome reduction in symbiotic bacteria. Nat. Rev. Microbiol. 10:13.

McFall-Ngai M., 2002. Unseen forces: the influence of bacteria on animal development. Dev. Biol. 242:1-14, doi:10.1006/dbio.2001.0522.

Medeiros J.M., Böck D., Pilhofer M. 2018. Imaging bacteria inside their host by cryo-focused ion beam milling and electron cryotomography. Curr. Opin. Microbiol. 43:62-68.

Medlin L., Elwood H.J., Stickel S., Sogin, M.L. 1988. The characterization of enzymatically amplified eukaryotic 16S-like rRNA-coding regions. Gene.71:491-499.

Meyer-Abich A. 1950. Beiträge zur theorie der evolution der organismen: typensynthese durch holobiose. E.J. Brill Archive, Leiden.

Minard G, Mavingui P., Moro C.V. 2013. Diversity and function of bacterial microbiota in the mosquito holobiont. Parasite. Vector. 6:146.

Mindell 1992. Phylogenetic consequences of symbioses: Eukarya and Eubacteria are not monophyletic taxa. BioSystems. 27:53-62.

Modeo L., Fokin S.I., Boscaro V., Andreoli I., Ferrantini F., Rosati G., Verni F., Petroni G. 2013a. Morphology, ultrastructure and molecular phylogeny of the ciliate Sonderia vorax with insights into the systematics of order Plagiopylida. BMC Microbiol. 13:40. doi: 10.1186/1471-2180-13-40.

Modeo L., Petroni G., Lobban C.S., Verni F., Vannini C. 2013b. Morphological, ultrastructural, and molecular characterization of Euplotidium rosati n. sp. (Ciliophora, Euplotida) from Guam. J. Eukaryot. Microbiol. 60:25-36. 
Montagna M., Chouaia B., Mazza G., Prosdocimi E.M., Crotti E., Mereghetti V., Vacchini V., Giorgi A., De Biase A., Longo S., Cervo R., Lozzia G.C., Alma A., Bandi C., Daffonchio D. 2015. Effects of the diet on the microbiota of the red palm weevil (Coleoptera: Dryophthoridae). PLoS One 10:e0117439. doi:10.1371/journal.pone.0117439.

Montagna M., Mereghetti V., Gargari G., Guglielmetti S., Faoro F., Lozzia G., Locatelli D., Limonta L. 2016. Evidence of a bacterial core in the stored products pest Plodia interpunctella: the influence of different diets. Environ. Microbiol. 18:4961-4973. doi: 10.1111/1462-2920.13450.

Molmeret M., Horn M., Wagner M., Santic M., Kwaik Y.A. 2005. Amoebae as training grounds for intracellular bacterial pathogens. Appl. Environ. Microbiol. 71:20-28.

Montesanto G. 2015. A fast GNU method to draw accurate scientific illustrations for taxonomy. ZooKeys. 515:191.

Moran N.A., Bennett G.M. 2014. The tiniest tiny genomes. Annu. Rev. Microbiol. 68:195-215.

Moran N.A., Sloan D.B. 2015. The hologenome concept: helpful or hollow? PLoS Biol. 13:e1002311.

Morin G.B., Cech T.R. 1986. The telomeres of the linear mitochondrial DNA of Tetrahymena thermophila consist of $53 \mathrm{bp}$ tandem repeats. Cell. 46:873-883.

Nitla V., Serra V., Fokin S.I., Modeo L., Verni F., Sandeep B.V., Kalavati C., Petroni G. 2019. Critical revision of the family Plagiopylidae (Ciliophora: Plagiopylea), including the description of two novel species, Plagiopyla ramani and Plagiopyla.narasimhamurthii, and redescription of Plagiopyla nasuta Stein, 1860 from India. Zool. J. Linnean. Soc. 186:1-45.

https://doi.org/10.1093/zoolinnean/zly041.

Nobili R., Rosati Raffaelli G. 1971. The fine structure of the oral apparatus of some ciliate Hypotrichs. Mon. Zool. Ital. 5:65-80.

Nowack E.C., Melkonian M. 2010. Endosymbiotic associations within protists. Philos. T. R. Soc. B. 365:699-712.

Nygren A., Parapar J., Pons J., Meißner K., Bakken T., Kongsrud J.A., Oug E., Gaeva D., Sikorski A., Johansen R.A., Hutchings P.A., Lavesque N., Capa M. 2018. A mega-cryptic species complex hidden among one of the most common annelids in the North East Atlantic. Plos One 13:0198356.

Ohkuma M. 2008. Symbioses of flagellates and prokaryotes in the gut of lower termites. Trends Microbiol. 16:345-352.

Osawa S., Jukes T.H. 1988. Evolution of the genetic code as affected by anticodon content. Trends Genet. 4:191-198.

Parks D.H., Chuvochina M., Waite D.W., Rinke C., Skarshewski A., Chaumeil P.A., Hugenholtz P. 2018. A standardized bacterial taxonomy based on genome phylogeny substantially revises the tree of life. Nat. Biotechnol. 36:996-1004. 
Pearce D.A., van der Gast C.J, Lawley B., Ellis-Evans J.C. 2003. Bacterioplankton community diversity in a maritime Antarctic lake, determined by culture-dependent and culture-independent techniques. FEMS Microbiol. Ecol. 45:59-70.

Petroni G., Dini F., Verni F., Rosati G. 2002. A molecular approach to the tangled intrageneric relationships underlying phylogeny in Euplotes (Ciliophora, Spirotrichea). Mol. Phylogenetics Evol. 22:118-130.

Petroni G., Spring S., Schleifer K.H., Verni F., Rosati G. 2000. Defensive extrusive ectosymbionts of Euplotidium (Ciliophora) that contain microtubule-like structures are bacteria related to Verrucomicrobia. Proc. Natl. Acad. Sci. 97:1813-1817.

Petz W., Song W., Wilbert N. 1995. Taxonomy and ecology of the ciliate fauna (Protozoa, Ciliophora) in the endopagial and pelagial of the Weddell Sea, Antarctica (Vol. 40). Land Oberösterreich, Ö̈ Landesmuseum.

Pinos S., Pontarotti P., Raoult D., Baudoin J.P., Pagnier, I. 2016. Compartmentalization in PVC super-phylum: evolution and impact. Biol. Direct. 11:38.

Postler T.S., Ghosh S. 2017. Understanding the holobiont: how microbial metabolites affect human health and shape the immune system. Cell Metab. 26:110-130.

Pradeu T., 2011. A mixed self: the role of symbiosis in development. Biological Theory 6:80-88, doi:10.1007/s13752-011-0011-5.

Price M.N., Dehal P.S., Arkin A.P. 2009. FastTree: computing large minimum evolution trees with profiles instead of a distance matrix. Mol. Biol. Evol. 26:1641-1650.

Quast C., Pruesse E., Yilmaz P., Gerken J., Schweer T., Yarza P, Peplies J., Glöckner F.O. 2013. The SILVA ribosomal RNA gene database project: improved data processing and web-based tools. Nucl. Acids Res. 41:D590-D596. https://doi.org/10.1093/nar/gks1219.

Queller D.C., Strassmann J.E. 2016. Problems of multi-species organisms: endosymbionts to holobionts. Biol. Philos. 31:855-873.

Romero-Pérez G.A., Ominski K.H., McAllister T.A., Krause D.O. 2011. Effect of environmental factors and influence of rumen and hindgut biogeography on bacterial communities in steers. Appl. Environ. Microbiol. 77:258-268.

Ronquist F., Teslenko M., van der Mark P., Ayres D.L., Darling A., Höhna D., Larget B., Liu L., Suchard M.A., Huelsenbeck J.P. 2012. MrBayes 3.2: Efficient Bayesian phylogenetic inference and model choice across a large model space. Syst. Biol. 61:539-542.

https://doi.org/10.1093/sysbio/sys029.

Rosati G., Modeo L. 2003. Extrusomes in ciliates: diversification distribution, and phylogenetic implications. J. Eukaryot. Microbiol. 50:383-400.

Rosati G., Modeo L., Melai M., Petroni G., Verni F. 2004. A multidisciplinary approach to describe Protists: a morphological, ultrastructural, and molecular study on Peritromus kahli (Ciliophora, Heterotrichea). J. Eukaryot. Microbiol. 51:49-59. 
Rosati G., Verni F., Lenzi P., Giambelluca M.A., Sironi M., Bandi C. 1998. Epixenosomes, peculiar epibionts of the ciliated protozoon Euplotidium itoi: what kind of organisms are they? Protoplasma 201:38-44.

Rosati G., Petroni G., Quochi S., Modeo L., Verni F. 1999. Epixenosomes: peculiar epibionts of the hypotrich ciliate Euplotidium itoi defend their host against predators. J. Eukaryot. Microbiol. 46:278-282.

Rosenberg E., Koren O., Reshef L., Efrony R., Zilber-Rosenberg I. 2007. The role of microorganisms in coral health, disease and evolution. Nat. Rev. Microbiol. 5:355-362.

Rosenberg E., Sharon G., Zilber-Rosenberg I. 2009. The hologenome theory of evolution contains Lamarckian aspects within a Darwinian framework. Environ. Microbiol. 11:2959-2962.

Rosenberg E., Zilber-Rosenberg I. 2011. Symbiosis and development: the hologenome concept. Birth Defects Res. C. 93:56-66.

Roughgarden J., Gilbert S.F., Rosenberg E., Zilber-Rosenberg I., Lloyd E.A. 2018. Holobionts as units of selection and a model of their population dynamics and evolution. Biol. Theory. 13:44-65.

Ruffolo J.J. 1976. Fine structure of the dorsal bristle complex and pellicle of Euplotes eurystomus, a ciliate protozoon. J. Morphol. 148:469-488.

Sakai T., Ishizuka K., Kato I. 2003. Isolation and characterization of a fucoidan-degrading marine bacterium. Mar. Biotechnol. 5:409-416.

Sanchez-Canizares C., Jorrin B., Poole P.S., Tkacz A. 2017. Understanding the holobiont: the interdependence of plants and their microbiome. Curr. Opin. Microbiol. 38:188-196.

Seemann T. 2013. barrnap 0.5: rapid ribosomal RNA prediction.

http://www.vicbioinformatics.com/

Seemann T. 2014. Prokka: rapid prokaryotic genome annotation. Bioinformatics 30:2068-9.

Scheid P. 2014. Relevance of free-living amoebae as hosts for phylogenetically diverse microorganisms. Parasitol. Res. 113:2407-2414

Schmitz-Esser S., Tischler P., Arnold R., Montanaro J., Wagner M., Rattei T., Horn M. 2010. The genome of the amoeba symbiont "Candidatus Amoebophilus asiaticus" reveals common mechanisms for host cell interaction among amoeba-associated bacteria. J. Bacteriol. 192:10451057.

Schrallhammer M., Ferrantini F., Vannini C., Galati S., Schweikert M., Görtz H.D., Verni F., Petroni G. 2013. 'Candidatus Megaira polyxenophila' gen. nov., sp. nov.: considerations on evolutionary history, host range and shift of early divergent rickettsiae. PLoS One. 8:e72581.

Schrallhammer M., Schweikert M., Vallesi A., Verni F., Petroni G. 2011. Detection of a novel subspecies of Francisella noatunensis as endosymbiont of the ciliate Euplotes raikovi. Microb. Ecol. 61:455-464. 
Schweikert M., Fujishima M., Görtz H.-D. 2013. Symbiotic associations between ciliates and prokaryotes. In: Rosenberg E., DeLong E.F., Stackebrandt E., Lory S., Thompson F., editors. The Prokaryotes - prokaryotic biology and symbiotic associations. Springer-Verlag, Berlin, pp. 427458.

Senra M.V., Dias R.J., Castelli M., Silva-Neto I.D., Verni F., Soares C.A., Petroni G. 2016. A house for two - double bacterial infection in Euplotes woodruffi Sq1 (Ciliophora, Euplotia) sampled in Southeastern Brazil. Microb. Ecol. 71:505-517.

Serra V., Fokin S.I., Castelli M., Basuri C.K., Nitla V.M., Verni F., Sandeep B.V., Kalavathi C., Petroni G. 2016. “Candidatus Gortzia shahrazadis”, a novelendosymb iont of Paramecium multimicronucleatum and revision of the biogeographical distribution of Holospora-like bacteria. Front. Microbiol. 7:1704. https://doi.org/10.3389/fmicb.2016.01704

Shao C., Ma H., Gao S., Khaled A.R.A., Song W. 2010. Reevaluation of cortical developmental patterns in Euplotes (sl), including a morphogenetic redescription of E. charon (Protozoa, Ciliophora, Euplotida). Chin. J. Ocean. Limnol. 28:593-602. https://doi.org/10.1007/s00343-0109128-9.

Schnare M.N., Heinonen T.Y., Young P.G., Gray M.W. 1986. A discontinuous small subunit ribosomal RNA in Tetrahymena pyriformis mitochondria. J. Biol. Chem. 261:5187-5193.

Skillings D. 2016. Holobionts and the ecology of organisms: Multi-species communities or integrated individuals? Biol. Philos. 31:875-892.

Skovorodkin I.N. 1990. A device for immobilization of small biological objects during light microscopical observation. Tsitologiia. 32:87-91.

Šlapeta J., Moreira D., López-García P. 2005. The extent of protist diversity: insights from molecular ecology of freshwater eukaryotes. Proc. R. Soc. Lond. B. Biol. Sci. 272:2073-2081.

Song W., Packroff G. 1997. Taxonomische Untersuchungen an marinen Ciliaten aus China mit Beschreibungen von zwei neuen Arten, Strombidium globosaneum nov. spec. and S. platum nov. spec.(Protozoa, Ciliophora). Arch. Protstenk. 147:331-360.

Stamatakis A. 2014. RAxML version 8: a tool for phylogenetic analysis and post-analysis of large phylogenies. Bioinformatics. 30:1312-1313.

Suyama Y, Miura K. 1968. Size and structural variations of mitochondrial DNA. Proc. Natl. Acad. Sci. USA 60:235-242.

Syberg-Olsen M.J., Irwin N.A., Vannini C., Erra F., Di Giuseppe G., Boscaro V., Keeling P.J. 2016. Biogeography and character evolution of the ciliate genus Euplotes (Spirotrichea, Euplotia), with description of Euplotes curdsi sp. nov. PloS one. 11:e0165442.

Swart E.C., Nowacki M., Shum J., Stiles H., Higgins B.P., Doak T.G., Schotanus K., Magrini V., Minx P., Mardis E.R., Landweber L.F. 2011. The Oxytricha trifallax mitochondrial genome. Genome Biol. Evol. 4:136-154. doi:10.1093/gbe/evr136.

Szokoli F., Castelli M., Sabaneyeva E., Schrallhammer M., Krenek S., Doak T.G., Berendonk T.U., Petroni G. 2016. Disentangling the taxonomy of Rickettsiales and description of two novel 
symbionts ("Candidatus Bealeia paramacronuclearis" and "Candidatus Fokinia cryptica") sharing the cytoplasm of the ciliate protist Paramecium biaurelia. Appl. Environ. Microbiol. 82:7236-7247

Takahashi S., Tomita J., Nishioka K., Hisada T., Nishijima M. 2014. Development of a prokaryotic universal primer for simultaneous analysis of bacteria and archaea using next generation sequencing. PloS one. 9:e105592.

Talavera G., Castresana J. 2007. Improvement of phylogenies after removing divergent and ambiguously aligned blocks from protein sequence alignments. Syst. Biol. 56:564-577.

Thompson J.R., Rivera H.E., Closek C.J., Medina M. 2015. Microbes in the coral holobiont: partners through evolution, development, and ecological interactions. Front. Cell. Infect. Microbiol. $4: 176$.

Tuffrau M. 1964. Le maintien des caractères speÂcifiques à travers le polymorphisme d'Euplotes balteatus. Archs. Zool. 104:143-151.

Tuffrau M., Fryd-Versavel G., Tuffrau H., Génermont J. 2000. Description of Euplotes versatilis n. sp., a marine tropical ciliate exhibiting an unusually extensive phenotypic plasticity. Eur. J.

Protistol. 36:355-366.

Valbonesi A., Luporini P. 1990a. Description of two new species of Euplotes and Euplotes rariseta from Antarctica. Polar Biol. 11:47-53.

Valbonesi A. and Luporini P. 1990b. A new marine species of Euplotes (Ciliophora, Hypotrichida) from Antarctica. Bull. Br. Mus. Nat. Hist. (Zool.) 56:57-61.

Valbonesi A. and Luporini P. 1995. Euplotes bisulcatus, a key species for a better understanding of the organization and evolution of Euplotes argyrome patterns. Eur. J. Protistol. 31: 32-37.

Vallesi A., Di Giuseppe G., Dini F., Luporini P. 2008. Pheromone evolution in the protozoan ciliate, Euplotes: the ability to synthesize diffusible forms is ancestral and secondarily lost. Mol. Phylogen. Evol. 47:439-442.

Vandekerckhove T.T., Willems A., Gillis M., Coomans A. 2000. Occurrence of novel verrucomicrobial species, endosymbiotic and associated with parthenogenesis in Xiphinema americanum-group species (Nematoda, Longidoridae). Int. J. Syst. Evol. Microbiol. 50:2197-2205.

Vandenkoornhuyse P., Quaiser A., Duhamel M., Le Van A., Dufresne A. 2015. The importance of the microbiome of the plant holobiont. New Phytol. 206:1196-1206.

Vannini C., Boscaro V., Ferrantini F., Benken K.A., Mironov T.I., Schweikert M., Görtz H.-D., Fokin S.I., Sabaneyeva E.V., Petroni G. 2014. Flagellar movement in two bacteria of the family Rickettsiaceae: a re-evaluation of motility in an evolutionary perspective. PLoS One. 9:e87718.

Vannini C., Ferrantini F., Schleifer K.H., Ludwig W., Verni F., Petroni G. 2010. “Candidatus Anadelfobacter veles" and "Candidatus Cyrtobacter comes," two new Rickettsiales species hosted by the protist ciliate Euplotes harpa (Ciliophora, Spirotrichea). Appl. Environment. Microbiol. 76:4047-4054. 
bioRxiv preprint doi: https://doi.org/10.1101/666461; this version posted June 11,2019 . The copyright holder for this preprint (which was not certified by peer review) is the author/funder, who has granted bioRxiv a license to display the preprint in perpetuity. It is made available under aCC-BY-NC-ND 4.0 International license.

Vallesi A., Sjödin A., Petrelli D., Luporini P., Taddei A.R., Thelaus J., Öhrman C., Nilsson E., Di Giuseppe G., Gutiérrez G., Villalobo, E. 2019. A new species of the $\gamma$-Proteobacterium Francisella, $F$. adeliensis sp. nov., endocytobiont in an antarctic marine ciliate and potential evolutionary forerunner of pathogenic species. Microb. Ecol. 1-10.

Vannini C., Ferrantini F., Verni F., Petroni G. 2013. A new obligate bacterial symbiont colonizing the ciliate Euplotes in brackish and freshwater: 'Candidatus Protistobacter heckmanni'. Aquat. Microb. Ecol. 70:233-243.

Vannini C., Rosati G., Verni F., Petroni G. 2004. Identification of the bacterial endosymbionts of the marine ciliate Euplotes magnicirratus (Ciliophora, Hypotrichia) and proposal of 'Candidatus Devosia euplotis'. Int. J. Sys.Evol. Microbiol. 54:1151-1156.

Vezzulli L., Pezzati E., Huete-Stauffer C., Pruzzo C., Cerrano C. 2013. 16SrDNA pyrosequencing of the Mediterranean gorgonian Paramuricea clavata reveals a link among alterations in bacterial holobiont members, anthropogenic influence and disease outbreaks. PloS one. 8:e67745.

Wagner M., Horn M. 2006. The Planctomycetes, Verrucomicrobia, Chlamydiae and sister phyla comprise a superphylum with biotechnological and medical relevance. Curr. Opin. Biotechnol. $17: 241-249$.

Walter D.E., Winterton S. 2007. Keys and the crisis in taxonomy: extinction or reinvention? Annu. Rev. Entomol. 52:193-208.

Wang M., Ahrne S., Jeppsson B., Molin G. 2005. Comparison of bacterial diversity along the human intestinal tract by direct cloning and sequencing of 16S rRNA genes. FEMS Microbiol. Ecol. 54:219-231.

Warren A., Patterson D.J., Dunthorn M., Clamp J.C., Achilles-Day U.E., Aescht E., Al-Farraj S.A., Al-Quraishy S., Al-Rasheid K., Carr M., Day J.G., Dellinger M., El-Serehy H.A., Fan Y., Gao F., Gao S., Gong J., Gupta R., Hu X., Kamra K., Langlois G., Lin X., Lipscomb D., Lobban C.S., Luporini P., Lynn D.H., Ma H., Macek M., Mackenzie-Dodds J., Makhija S., Mansergh R.I., Martín-Cereceda M., McMiller N., Montagnes D.J.S., Nikolaeva S., Ong'ondo G.O., Pérez-Uz B., Purushothaman J., Quintela-Alonso P., Rotterová J., Santoferrara L., Shao C., Shen Z., Shi X., Song W., Stoeck T., La Terza A., Vallesi A., Wang M., Weisse T., Wiackowski K., Wu L., Xu K., Yi Z., Zufall R., Agatha S. 2017. Beyond the 'Code': a guide to the description and documentation of biodiversity in ciliated protists (Alveolata, Ciliophora). J. Eukaryot. Microbiol. 64:539-554.

Washburn E.S., Borror A.C. 1972. Euplotes raikovi Agamaliev, 1966 (Ciliophora, Hypotrichida) from New Hampshire: description and morphogenesis. J. Protozool. 19:604-608.

van de Water J.A., Allemand D., Ferrier-Pagès C. 2018. Host-microbe interactions in octocoral holobionts-recent advances and perspectives. Microbiome. 6:64.

Weisse T. 2008. Distribution and diversity of aquatic protists: an evolutionary and ecological perspective. Biodivers. Conserv. 17:243-259.

Westram R., Bader K., Pruesse E., Kumar Y., Meier H., Glöckner F.O., Ludwig W. 2011. ARB: a software environment for sequence data. In: de Bruijn F.J., editor. Handbook of molecular 
microbial ecology I: Metagenomics and complementary approaches. Wiley-Blackwell Publishing, pp. 399-406. https://doi.org/10.1002/9781118010518.ch46

Wilson A.C.C., Ashton P.D., Calevro F., Charles H., Colella S., Febvay G., Jander G., Kushlan P.F., Macdonald S.J., Schwartz J.F., Thomas G.H., Douglas A.E. 2010. Genomic insight into the amino acid relations of the pea aphid, Acyrthosiphon pisum, with its symbiotic bacterium Buchnera aphidicola. Insect. Mol. Biol. 19:249-258.

Ya'cob Z., Takaoka H., Low V.L., Sofian-Azirun M. 2017. First description of a new cryptic species, Simulium vanluni from Peninsular Malaysia: an integrated morpho-taxonomical and genetic approach for naming cryptic species in the family Simuliidae. Acta. Trop. 167:31-39.

Yildirim S., Yeoman C.J., Sipos M., Torralba M., Wilson B.A., Goldberg T.L., Stumpf R.M., Leigh S.R., White B.R., Nelson K.E. 2010. Characterization of the fecal microbiome from non-human wild primates reveals species specific microbial communities. PloS one. 5:13963.

Yoon J. 2011. Phylogenetic studies on the bacterial phylum 'Verrucomicrobia'. Microbiol. Cult. Coll. 27:61-65.

Yoon J., Matsuo Y., Matsuda S., Kasai H., Yokota A. 2010. Cerasicoccus maritimus sp. nov. and Cerasicoccus frondis sp. nov., two peptidoglycan-less marine verrucomicrobial species, and description of Verrucomicrobia phyl. nov., nom. rev. J. Gen. Appl. Microbiol. 56:213-222.

Zhang L., Xu Z. 2008. Assessing bacterial diversity in soil. J. Soils Sediments. 8:379-388.

Zilber-Rosenberg I., Rosenberg E. 2008. Role of microorganisms in the evolution of animals and plants: the hologenome theory of evolution. FEMS Microbial. Rev. 32:723-735. 


\section{TABLES}

Table 1. Morphometric data for Euplotes vanleeuwenhoeki sp. nov.

\begin{tabular}{lllll}
\hline Character & MIN-MAX & $X \pm$ SD & CV & n \\
\hline
\end{tabular}

\section{Body length $(\mu \mathrm{m})$}

$\begin{array}{lllll}\text { Live } & 39.5-58.0 & 49.1 \pm 4.7 & 9.7 & 22 \\ \text { SI } & 38.9-50.3 & 45.6 \pm 3.1 & 6.7 & 37\end{array}$

\section{Body width $(\mu \mathrm{m})$}

$\begin{array}{lllcr}\text { Live } & 24.9-37.8 & 32.7 \pm 3.8 & 11.6 & 22 \\ \text { SI } & 21.6-35.5 & 29.1 \pm 4.1 & 14.0 & 37\end{array}$

Macronucleus lenght ( $\mu \mathrm{m})$

Feulgen staining

28.9-48.6 $\quad 36.6 \pm 4.5$

12.4

Macronucleus width $(\mu \mathrm{m})$

Feulgen staining

4.3-7.2

$5.7 \pm 1.0$

17.3

Micronucleus diameter $(\mu \mathrm{m})$

Feulgen staining

$\begin{array}{ll}1.8-2.3 & 2.0 \pm 0.2\end{array}$

9.0

15

MIN: minimum value; MAX: maximum value; X: arithmetic mean; SD: standard deviation; $\mathrm{CV}$ : coefficient of variation (\%); n: number of specimens analyzed; SI: silver impregnation. 
bioRxiv preprint doi: https://doi.org/101101/666461; this version posted June 11, 2019. The copyright holder for this preprint (which was not certified by peer review) is the author/funder, who has granted bioRxiv a license to display the preprint in perpetuity. It is made available under aCC-BY-NC-ND 4.0 International license.

Table 2. Morphological comparison between Euplotes vanleeuwenhoeki sp. nov. and selected congeners

\begin{tabular}{|c|c|c|c|c|c|c|}
\hline Character & $\begin{array}{c}\text { Euplotes } \\
\text { vanleeuwenhoeki }\end{array}$ & E. trisulcatus & $\begin{array}{c}E . \\
\text { antarcticus }\end{array}$ & E. euryhalinus & E. charon & $\begin{array}{c}\text { E. } \\
\text { magnicirratus }\end{array}$ \\
\hline $\begin{array}{l}\text { Body size in } \\
\text { vivo }(\mu \mathrm{m})\end{array}$ & $40-58 \times 25-38$ & $\begin{array}{c}35-50 \times 25- \\
40\end{array}$ & $\begin{array}{c}90-145 \times \\
30-80\end{array}$ & $50-62 \times 26-38$ & $\begin{array}{c}70-100 \times \\
65-90\end{array}$ & $51-65 \times 36-44$ \\
\hline Body shape & $\begin{array}{l}\text { Elongated } \\
\text { ellipsoidal; } \\
\text { posterior end } \\
\text { rounded }\end{array}$ & $\begin{array}{l}\text { Elongated } \\
\text { ellipsoidal; } \\
\text { posterior end } \\
\text { pointed }\end{array}$ & $\begin{array}{l}\text { Elongated } \\
\text { ellipsoidal; } \\
\text { posterior end } \\
\text { rounded }\end{array}$ & $\begin{array}{c}\text { Elongated oval; } \\
\text { posterior end } \\
\text { pointed }\end{array}$ & $\begin{array}{l}\text { Oval; } \\
\text { posterior end } \\
\text { rounded }\end{array}$ & $\begin{array}{l}\text { Oval; posterior } \\
\text { end rounded }\end{array}$ \\
\hline $\begin{array}{l}\text { Peristome ( } \% \\
\text { of the body } \\
\text { length) }\end{array}$ & 63 & 75 & 65 & 67 & 75 & 75 \\
\hline $\begin{array}{l}\text { Number, type } \\
\text { of dorsal } \\
\text { structures }\end{array}$ & $\begin{array}{l}\text { 3, prominent } \\
\text { furrows }\end{array}$ & $\begin{array}{l}\text { 3, prominent } \\
\text { furrows }\end{array}$ & $\begin{array}{l}7-10, \\
\text { prominent } \\
\text { DR }\end{array}$ & $\begin{array}{c}\text { Several, } \\
\text { inconspicious } \\
\text { DR }\end{array}$ & $\begin{array}{l}\text { 7, prominent } \\
\text { DR }\end{array}$ & $\begin{array}{c}\text { Several, } \\
\text { prominent DR }\end{array}$ \\
\hline $\begin{array}{l}\text { Number of } \\
\text { AZM }\end{array}$ & $22-29$ & $25-36$ & $46-56$ & $26-28$ & $51-60$ & $49-52$ \\
\hline $\begin{array}{l}\text { Dargyrome } \\
\text { type }\end{array}$ & $\begin{array}{c}\text { Double- } \\
\text { eurystomus }\end{array}$ & $\begin{array}{c}\text { Double- } \\
\text { eurystomus }\end{array}$ & $\begin{array}{c}\text { Double- } \\
\text { eurystomus }\end{array}$ & $\begin{array}{c}\text { Double- } \\
\text { eurystomus }\end{array}$ & $\begin{array}{c}\text { Double- } \\
\text { eurystomus }\end{array}$ & $\begin{array}{c}\text { Double- } \\
\text { eurystomus }\end{array}$ \\
\hline $\begin{array}{l}\text { Number of } \\
\text { dorsolateral } \\
\text { kineties }\end{array}$ & $7-8$ & 7 & $10-11$ & 10 & $9-10$ & 8 \\
\hline $\begin{array}{l}\text { Number of } \\
\text { dikinetids in } \\
\text { mid-dorsal row }\end{array}$ & 13-14 & $7-10$ & $11-21$ & 10 & 22 & $13-17$ \\
\hline $\begin{array}{l}\text { Number of } \\
\text { FVC }\end{array}$ & 10 & 10 & 10 & 10 & 10 & 10 \\
\hline Number of TC & 5 & 5 & 5 & 5 & 5 & 5 \\
\hline Number of CC & 2 & 2 & $3-4$ & $2-3$ & $2-4$ & 2 \\
\hline Number of MC & 2 & 2 & 2 & 2 & 2 & 2 \\
\hline Habitat & Freshwater & Marine & Marine & Euryhaline & Marine & Marine \\
\hline References & This study & Carter 1972 & $\begin{array}{l}\text { Petz et al. } \\
1995\end{array}$ & $\begin{array}{l}\text { Valbonesi and } \\
\text { Luporini 1990a }\end{array}$ & $\begin{array}{l}\text { Song and } \\
\text { Packroff } \\
\text { 1997; Shao } \\
\text { et al. } 2010\end{array}$ & Carter 1972 \\
\hline
\end{tabular}

AZM: adoral zone of membranelles; CC: caudal cirri; DR: dorsal ridge; FVC: frontoventral cirri; MC: marginal cirri; TC: transverse cirri. 
bioRxiv preprint doi: https://doi.org/10.1101/666461; this version posted June 11,2019 . The copyright holder for this preprint (which was not certified by peer review) is the author/funder, who has granted bioRxiv a license to display the preprint in perpetuity. It is made available under aCC-BY-NC-ND 4.0 International license.

\section{FIGURE LEGENDS}

FiguRE 1. Morphology of Euplotes vanleeuwenhoeki sp. nov. A) Schematic drawings of the dorsal side (left), ventral side (right), and nuclear apparatus (middle); B) Live picture, ventral side. C) Live picture, dorsal side; D) Feulgen staining, showing macronucleus (Ma) and micronucleus (Mi); E) Silver staining, dorsal side; F) Silver staining, ventral side; G-J) SEM pictures of dorsal side $(\mathrm{G})$, ventral side $(\mathrm{H})$, and lateral views (I-J); Arrow: paroral membrane; Arrowhead: dorsal furrow; Double arrowhead: food vacuole containing algae; AZM: adoral zone of membranelles; $\mathrm{Br}$ : bristle; CA: cortical ampules; CC: caudal cirri; CV: contractile vacuole; FVC: fronto-ventral cirri; Ma: macronucleus; MC: marginal cirri; Mi: micronucleus; MK: mid-dorsal kinety; TC: transverse cirri. Bars stand for $10 \mu \mathrm{m}$.

FIGURE 2. TEM picture of Euplotes vanleeuwenhoeki sp. nov. A-C) Cortex region; D-F) Oral region; A) Ciliary pit (CP) with dikinetid (Dk); B) Detail of bristle pit containing filamentous material (arrowhead); cortical ampules (CA) are visible; C) Transverse section of dikinetid (Dk) surrounded by cortical ampules; sections of the macronucleus (Ma), two mitochondria (Mt) and an endosymbiotic bacterium (arrow) are visible; D) Detail of oral membranelles, composed of two longer rows $(1,2)$ and one shorter row (3) of cilia; membranelles are separated by ridges (R); E) Section of oral region, showing paraoral membrane $(\mathrm{Pa})$ in front of oral membranelles and pharingeal disks (PD); F) Closer view of paraoral membrane and transverse section of macronucleus; G) Endosymbiotic bacterial cells (arrow) inside Euplotes cytoplasm, nearby macronucleus and micronucleus $(\mathrm{Mi})$; rosettes of glycogen $(\mathrm{G})$ and lipid droplets (L) are present; $\mathrm{L}$ ) Detail of contractile vacuole (CV) and transverse cirrus (TC); I) Section of cirrus (double arrowhead), close to mitochondria; J) Two phagosomes (Ph). CA: cortical ampules; CP: ciliary pit; CV: contractile vacuole; Dk: dikinetid; G: rosette of glycogen; L: lipid droplet; Ma macronucleus; Mi micronucleus; Mt: mitochondrion; Pa: paraoral membrane; PD: pharingeal disk; Ph: phagosome; R: ridge; TC: transverse cirrus; Arrowhead: filamentous material; Arrow: endosymbiotic bacterium; Double arrowhead: transverse section of cirrus. Bars stand for $1 \mu \mathrm{m}$.

Figure 3. Phylogenetic tree of genus Euplotes based on the $18 \mathrm{~S}$ rRNA gene. Numbers associated to nodes represent posterior probabilities and bootstrap values, respectively (only values above $0.80-75$ are shown). Sequence obtained in the present work is in bold.

FIGURE 4. Mitochondrial gene map of Euplotes vanleeuwenhoeki sp. nov. The gene map of the mitochondrial genome of E. vanleeuwenhoeki in comparison with those belonging to Euplotes minuta and Oxytricha trifallax is represented. Homologous regions among the three genomes are indicated by pale coloured areas. Names of split genes are suffixed by a letter or a lowercase Roman numeral. The direction of transcription is indicated by an arrow at each end of the mitochondrial map.

Figure 5. TEM pictures of "Candidatus Pinguicoccus supinus". A) Endosymbiont cells (arrow) in host cytoplasm, lying underneath the cortex, aggregated in clusters; macronucleus (Ma) and some mitochondria (Mt), also in proximity or in apparent close contact with endosymbionts, are visible; B) Closer view of "Ca. Pinguicoccus supinus" showing inner membrane (IM) and outer membrane 
(OM); an invagination of the inner membrane (IM) is present (arrowhead); C) Different cell shapes of three "Ca. Pinguicoccus supinus" specimens (arrow), from rounded to ovoid; the inner membrane is invaginated (arrowhead); D) Endosymbiont cell with an irregular shape, with and evident nucleoid $(\mathrm{Nu})$ and an evagination of the outer membrane (double arrowhead); E-F) " $C a$. Pinguicoccus supinus" cells showing evagination of the outer membrane (double arrowhead); F) Endosymbiont cell in proximity to a mitochondrion; G) " $\mathrm{Ca}$. Pinguicoccus supinus" showing emphasized folding (asterisk) of membrane area; H) Endosymbiont cells (arrow) appear to be in close contact with lipid droplets (L); I) " $C a$. Pinguicoccus supinus" (arrow) during binary fission; the division septum is well visible. IM: inner membrane; L: lipid droplet; Ma: macronucleus; Mt: mitochondrion; Nu: nucleoid; OM: outer membrane; Arrow: "Ca. Pinguicoccus supinus" cell; Arrowhead: evagination of the outer membrane; Asterisk: folding of membrane area; Double arrowhead: section of bacterial cell folding. Bars stand for $1 \mu \mathrm{m}(\mathrm{A}-\mathrm{F}, \mathrm{H}-\mathrm{I})$ and $0.5 \mu \mathrm{m}(\mathrm{G})$.

FIgURE 6. COG analysis of "Candidatus Pinguicoccus supinus" and other bacteria with highly reduced genome. A) Principal Component Analysis of numerosity in COG classes; explained variance by Component one 32\%; explained variance by Component two 24\%; B) Distribution of COGs in each analysed genome; C) Distribution of COGs, showing: i. percentage of COGs shared by all the analysed genomes, COGs unique for each genome, and COGs shared by at least two genomes; ii. Number of organisms sharing COGs. Each set groups together the COGs shared by a given number of organisms (i.e. 1, 2, 3...7), regardless of their identity; iii. Percentage of unique COGs in analyzed genomes.

FIgURE 7. Phylogenetic tree of Phylum Verrucomicrobia, based on the 16S rRNA gene. The phylogenetic position of "Candidatus Pinguicoccus supinus" is shown. Numbers associated to nodes represent posterior probability and bootstrap values, respectively (only values above 0.80-75 are shown). Black circles indicate organisms also employed in phylogenomic analysis (Fig. 8). Asterisks indicate sequences employed in the 16S rRNA gene screening on IMNGS (Fig. 10; Supplementary Table 9). Numbers in square brackets, associated to collapsed branches, indicate how many sequences are not shown (for list of hidden sequences see Supplementary Table 4). Sequence obtained in the present work is in bold.

FIgURE 8. Phylogenomic tree of Verrucomicrobia, showing evolutionary relationships of "Candidatus Pinguicoccus supinus". Numbers associated to nodes represent bootstrap values (only values above 75 are shown). Black circles indicate organisms also employed in phylogenetic analysis (Fig. 7). Genome of "Ca. Pinguicoccus supinus" obtained in the present work is in bold (accession number: CP039370).

FIGURE 9. Fluorescence in situ hybridization experiments on Euplotes vanleeuwenhoeki sp. nov. A-C) Specimen hybridized with probe EUB338 VII. D-F) Two specimens hybridized with probe Pingui_1174. A), D) Pictures at DIC microscope of fixed cells; B), E) DAPI staining, showing position of nuclear apparatus; C) Cell positive to probe EUB338 VII, fluorophore emitting in red (Cyanine-3); F) Cell positive to probe Pingui_1174, fluorophore emitting in red (Cy-3). Bars stand for $10 \mu \mathrm{m}$. 
bioRxiv preprint doi: https://doi.org/10.1101/666461; this version posted June 11,2019 . The copyright holder for this preprint (which was not certified by peer review) is the author/funder, who has granted bioRxiv a license to display the preprint in perpetuity. It is made available under aCC-BY-NC-ND 4.0 International license.

Figure 10. Diversity of "Candidatus Pinguicoccus supinus" based on 16S rRNA gene amplicon search in IMNGS. 16S rRNA gene hypervariable regions phylogenetic trees. OTUs were clustered with $99 \%$ identity and were longer than $300 \mathrm{bp}$. A total number of 90 OTUs were separated for each hypervariable region taken into analysis: 29 for V1-V2, 60 for V4-V6, 2 for V7V8. Complete 16S rRNA gene was employed in the analysis to enlighten the diversity of " $\mathrm{Ca}$. Pinguicoccus supinus". 
bioRxiv preprint doi: https://doi org/10.1101/666461; this version posted June 11,2019. The copyright holder for this preprint (which was

not certified by peer review) is the author/funder, who has granted bioRxiv a license to display the preprint in perpetuity. It is made available under aCC-BY-NC-ND 4.0 International license.

Figure 1
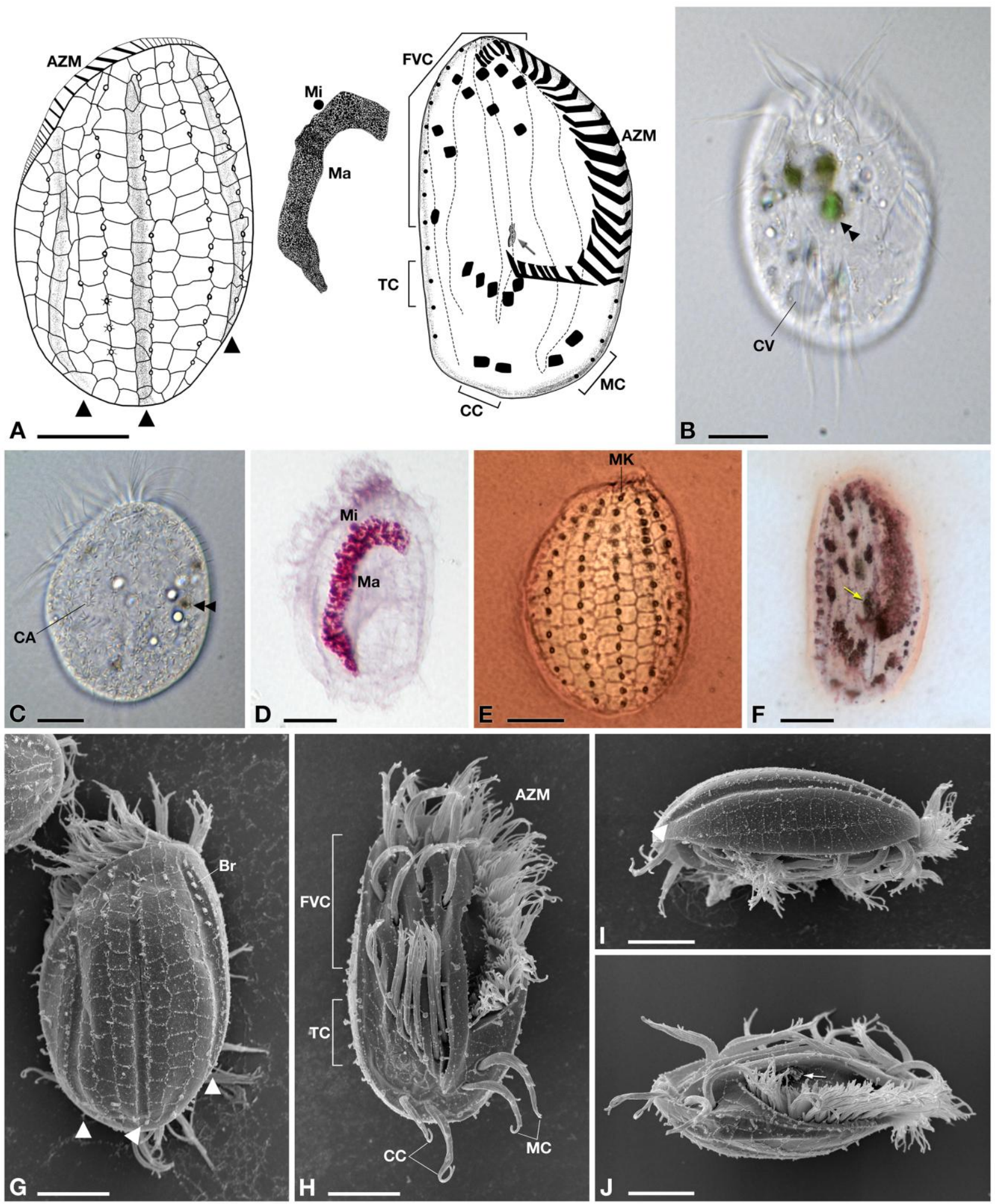
bioRxiv preprint doi: https://doi.org/10.1101/666461; this version posted June 11,2019. The copyright holder for this preprint (which was

not certified by peer review) is the author/funder, who has granted bioRxiv a license to display the preprint in perpetuity. It is made available under aCC-BY-NC-ND 4.0 International license.

\section{Figure 2}

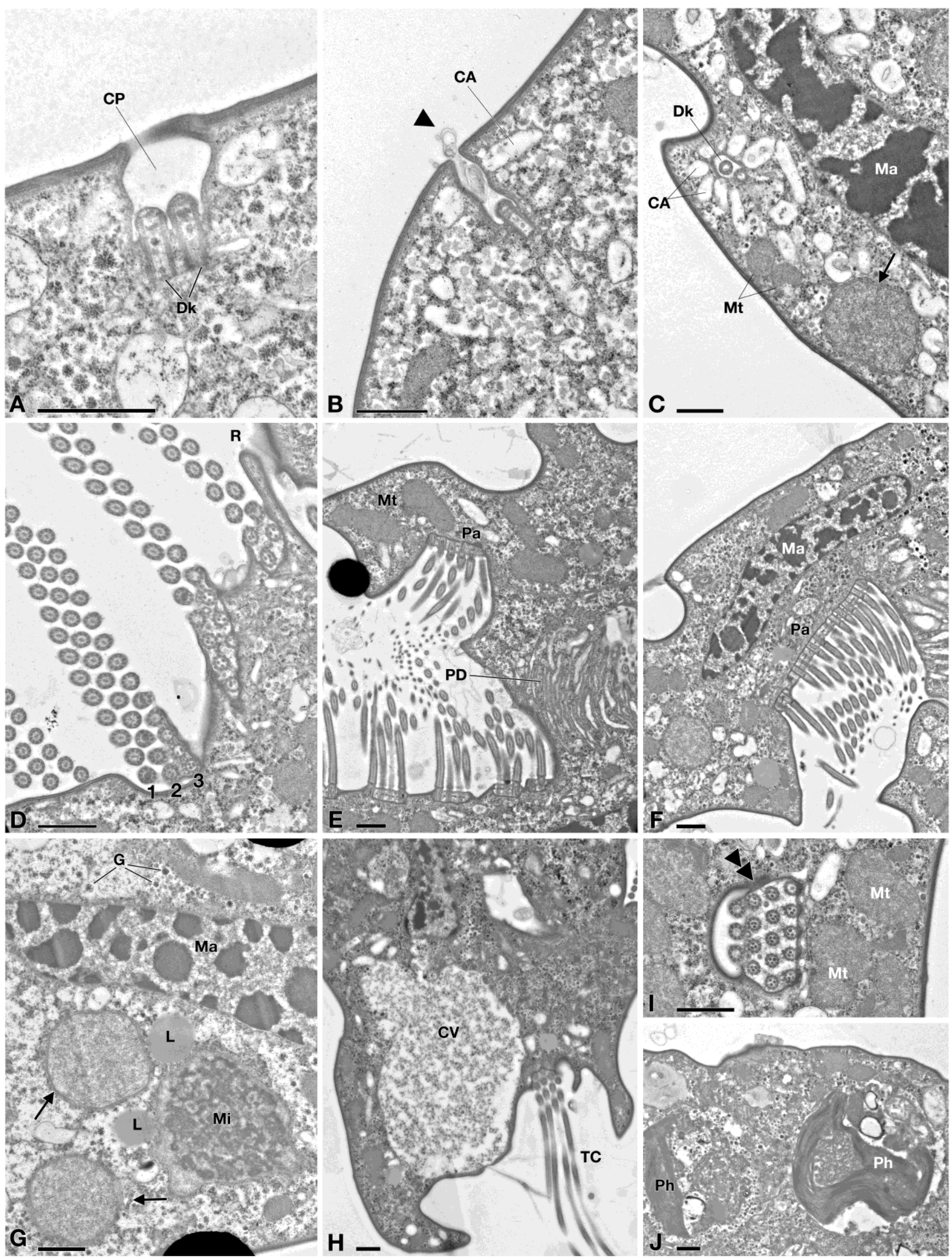


bioRxiv preprint doi: https://doi.org/10.1101/666461; this version posted June 11,2019 . The copyright holder for this preprint (which was not certified by peer review) is the author/funder, who has granted bioRxiv a license to display the preprint in perpetuity. It is made available under aCC-BY-NC-ND 4.0 International license.

\section{Figure 3}

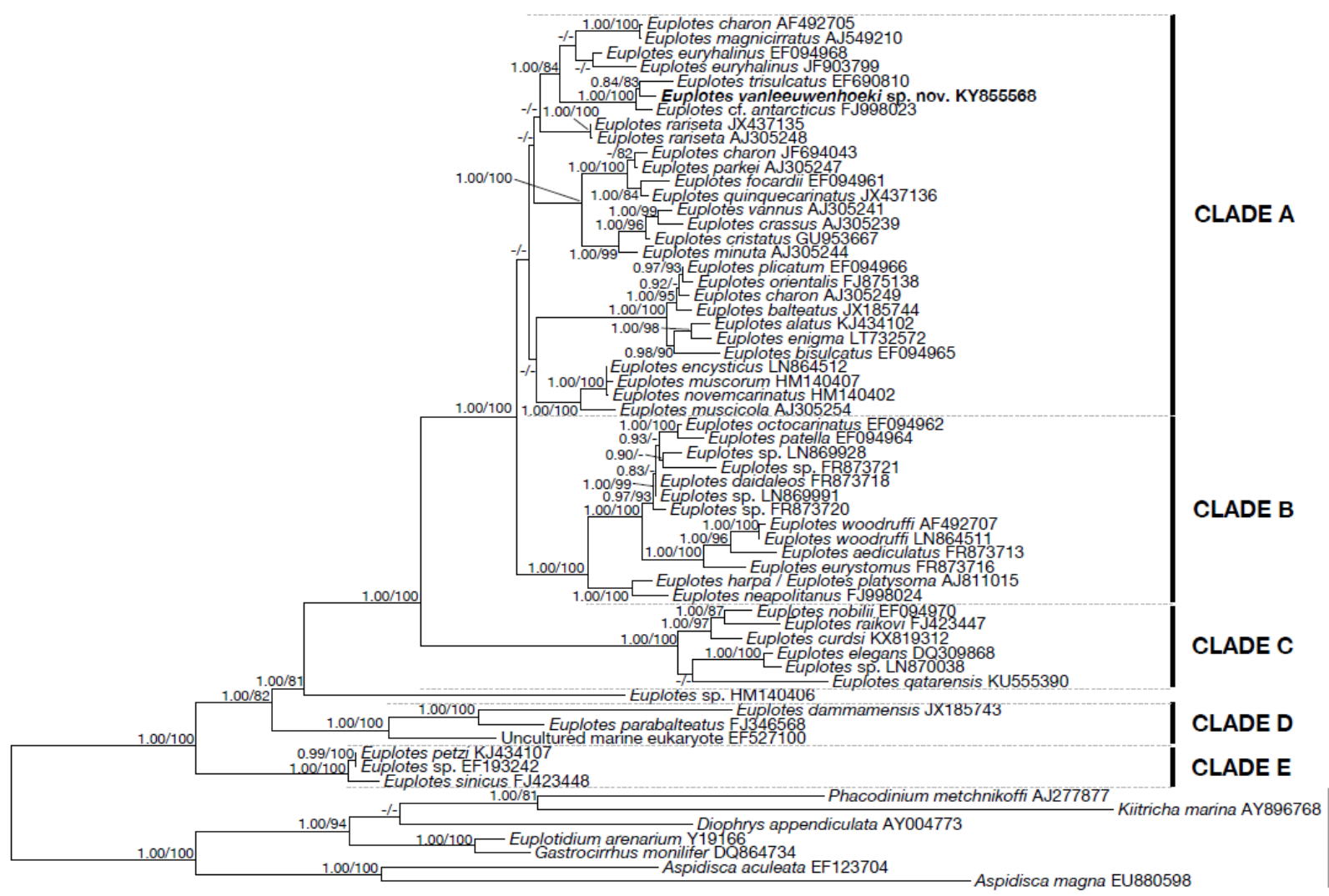


bioRxiv preprint doi: https://doi.org/10.1101/666461; this version posted June 11,2019. The copyright holder for this preprint (which was

not certified by peer review) is the author/funder, who has granted bioRxiv a license to display the preprint in perpetuity. It is made available under aCC-BY-NC-ND 4.0 International license.

\section{Figure 4}

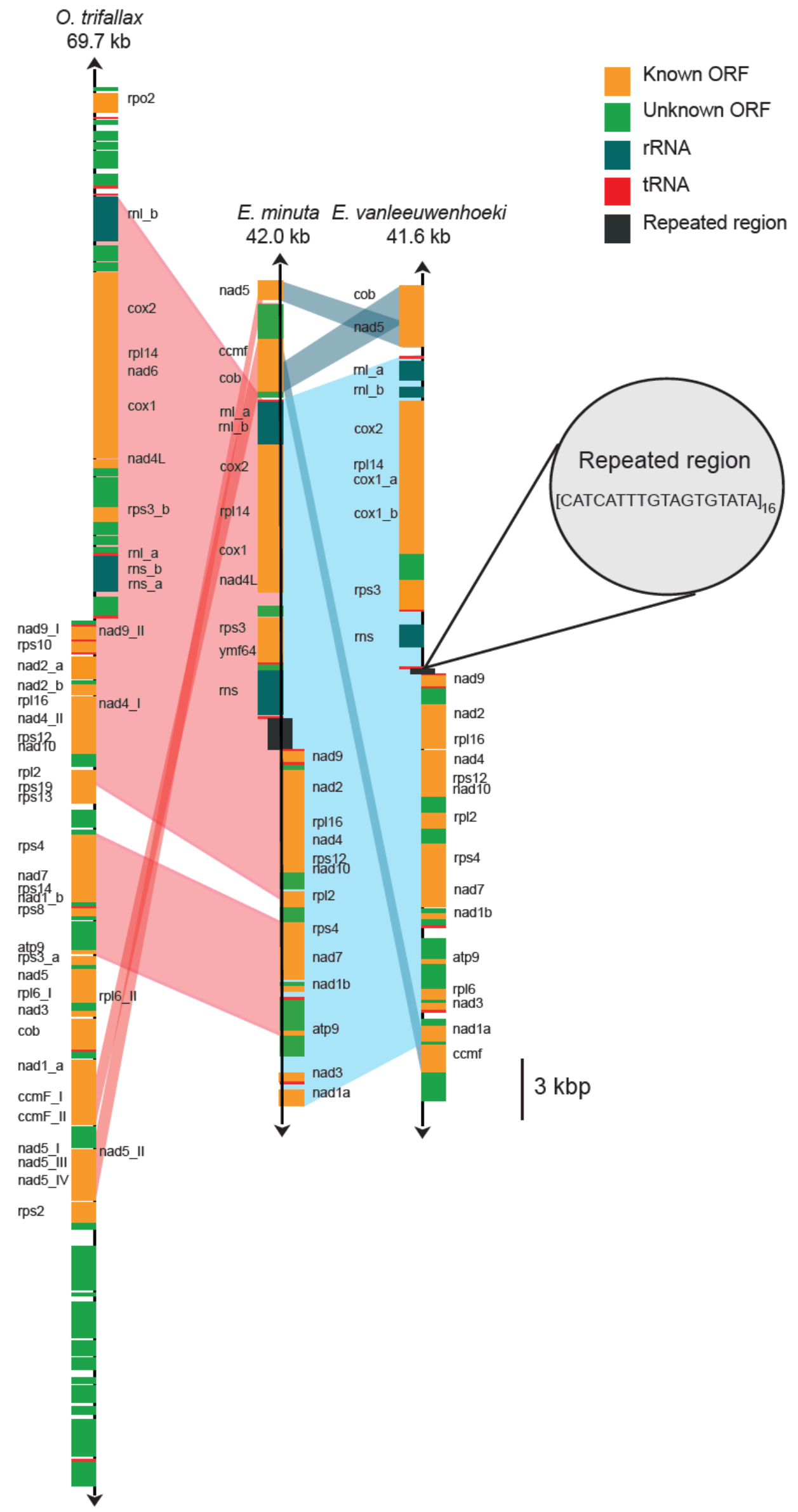


bioRxiv preprint doi: https://doi.org/10.1101/666461; this version posted June 11,2019. The copyright holder for this preprint (which was

not certified by peer review) is the author/funder, who has granted bioRxiv a license to display the preprint in perpetuity. It is made available under aCC-BY-NC-ND 4.0 International license.

\section{Figure 5}

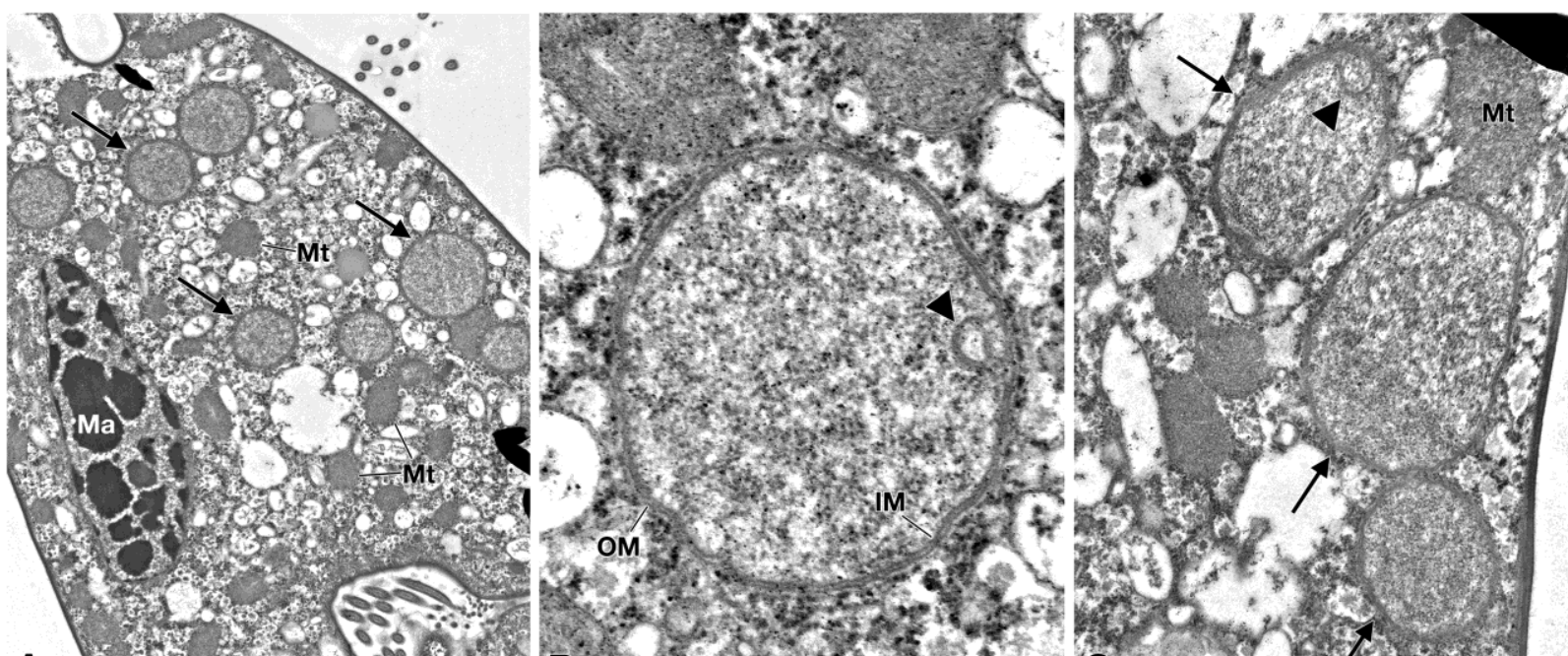

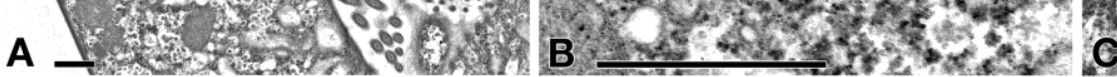
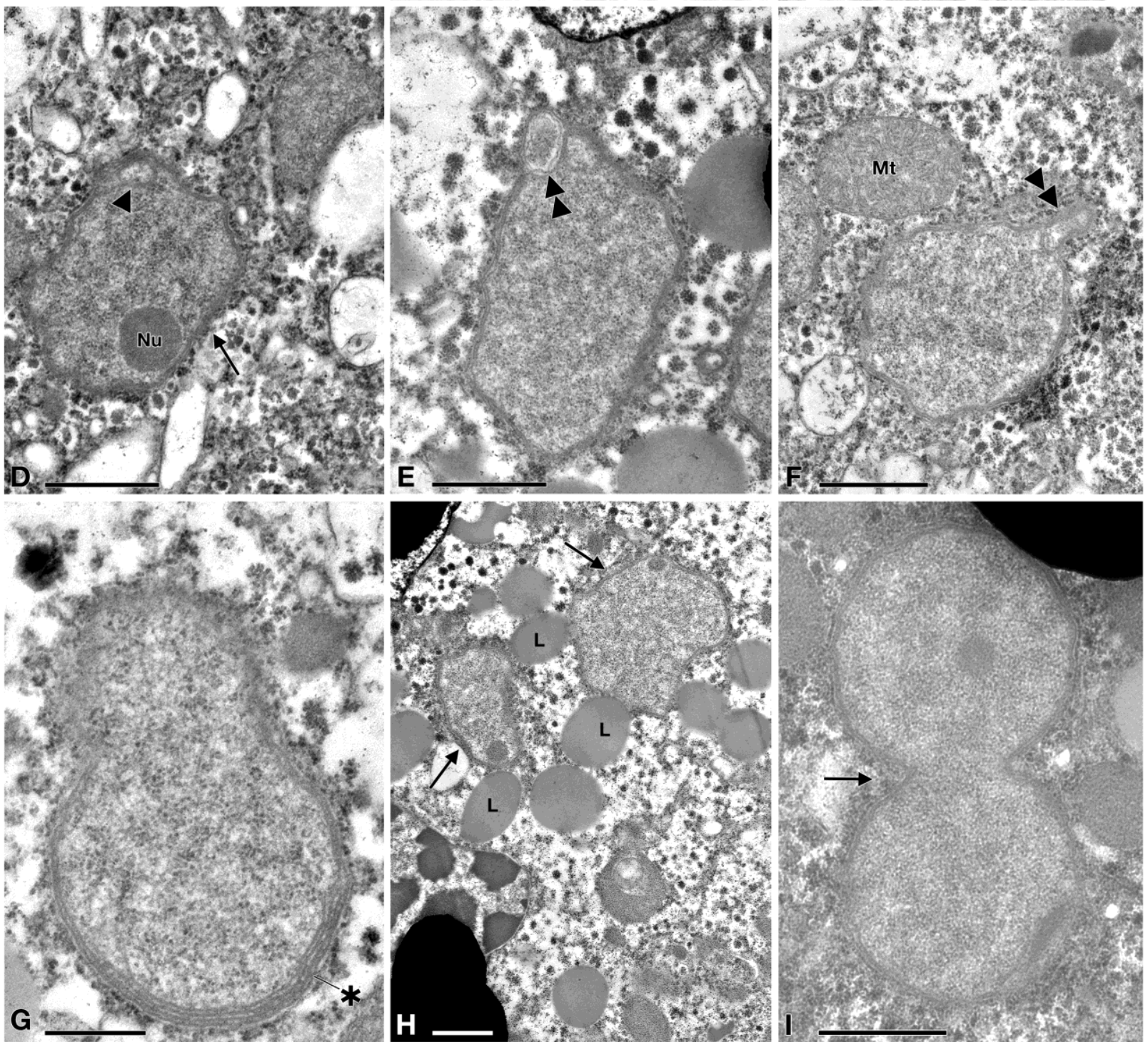
bioRxiv preprint doi: https://doi.org/10.1101/666461; this version posted June 11 2019. The copyright holder for this preprint (which was

not certified by peer review) is the author/funder, who has granted bioRxiv a license to display the preprint in perpetuity. It is made available under aCC-BY-NC-ND 4.0 International license.

\section{Figure 6}

A

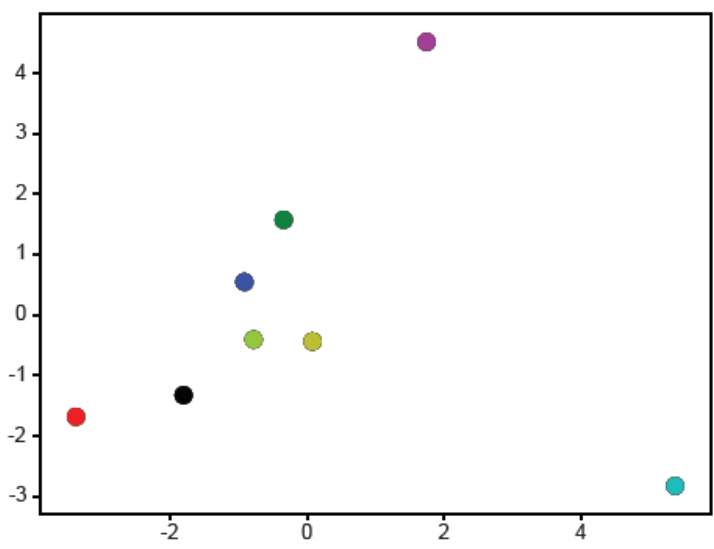

- "Ca. Carsonella rudii"

- "Ca. Hodgkinia cicadicola"

- "Ca. Sulcia muelleri"

- "Ca. Pinguicoccus supinus"
- "Ca. Zinderia insetticola"

- "Ca. Tremblaya princeps"

- "Ca. Tremblaya phenacola"

- "Ca. Nasuia deltocephalinicola"
B
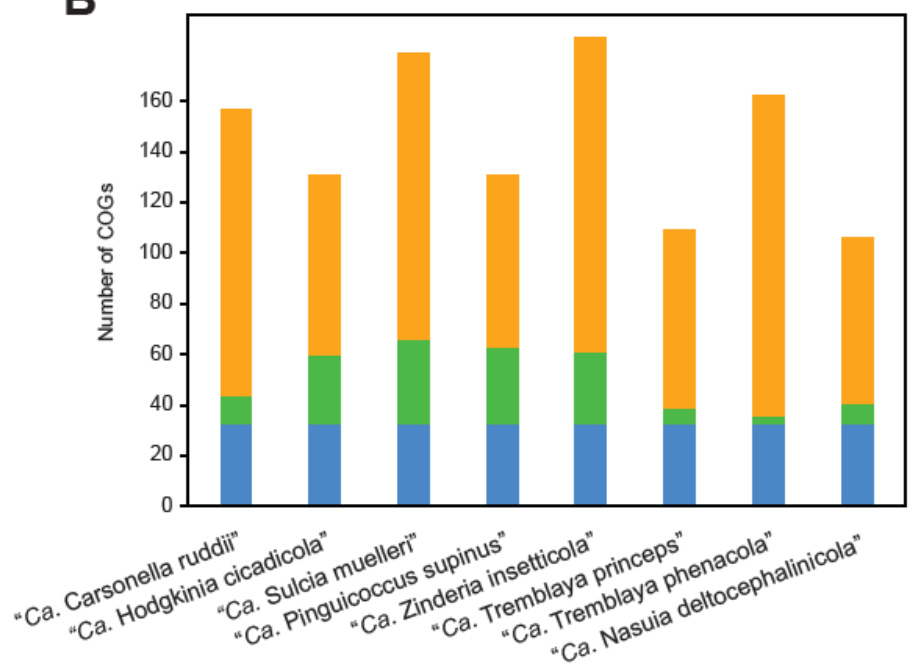

COGs shared by all genomes Uniques COGs COGs shared by two or more genomes

\section{C}

\section{i. COGs distribution}

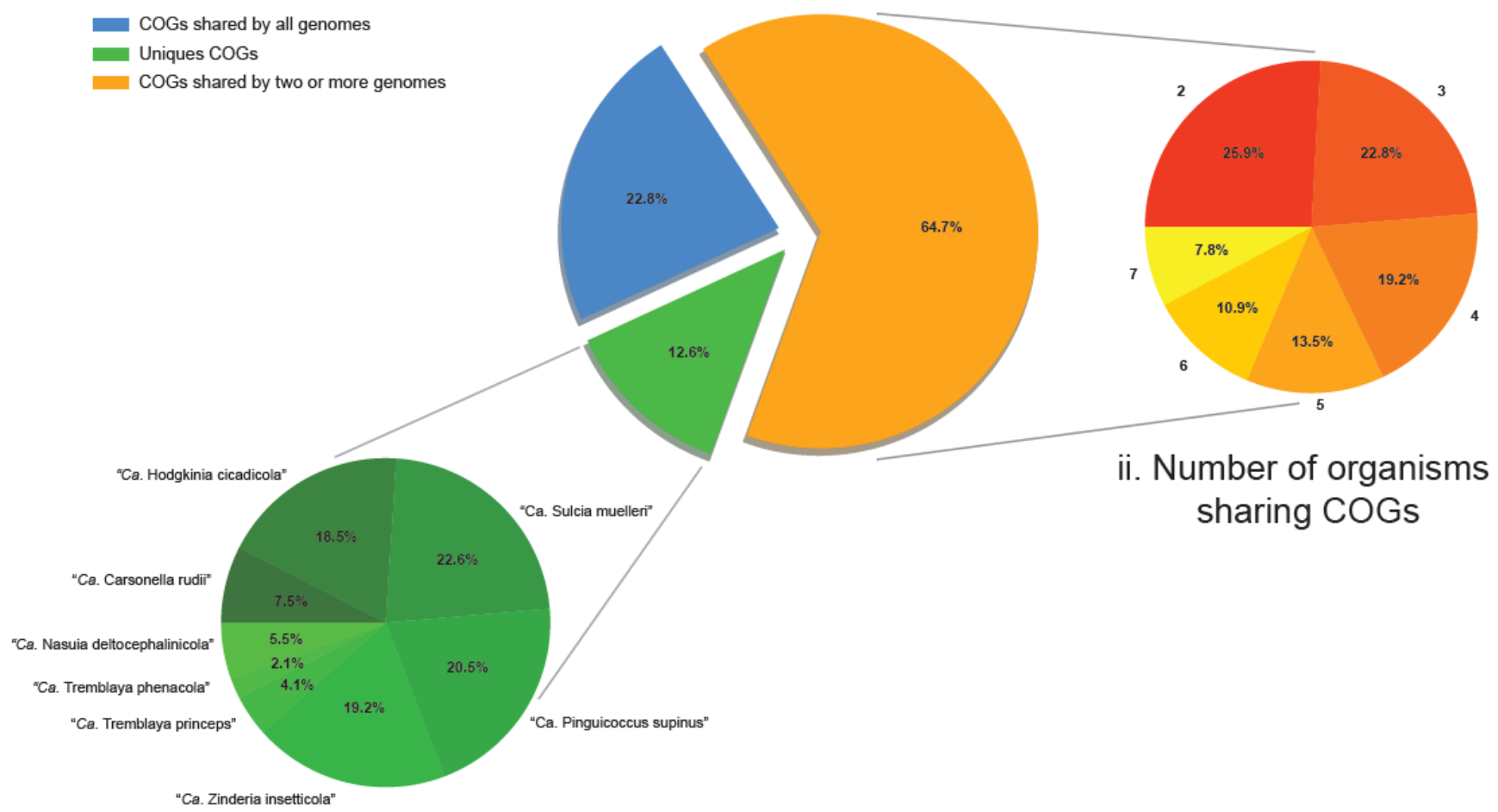

iii. \% of unique COGs in Analyzed genomes 
bioRxiv preprint doi: https://doi.org/10.1101/666461; this version posted June 11,2019 . The copyright holder for this preprint (which was

not certified by peer review) is the author/funder, who has granted bioRxiv a license to display the preprint in perpetuity. It is made available under aCC-BY-NC-ND 4.0 International license.

Figure 7

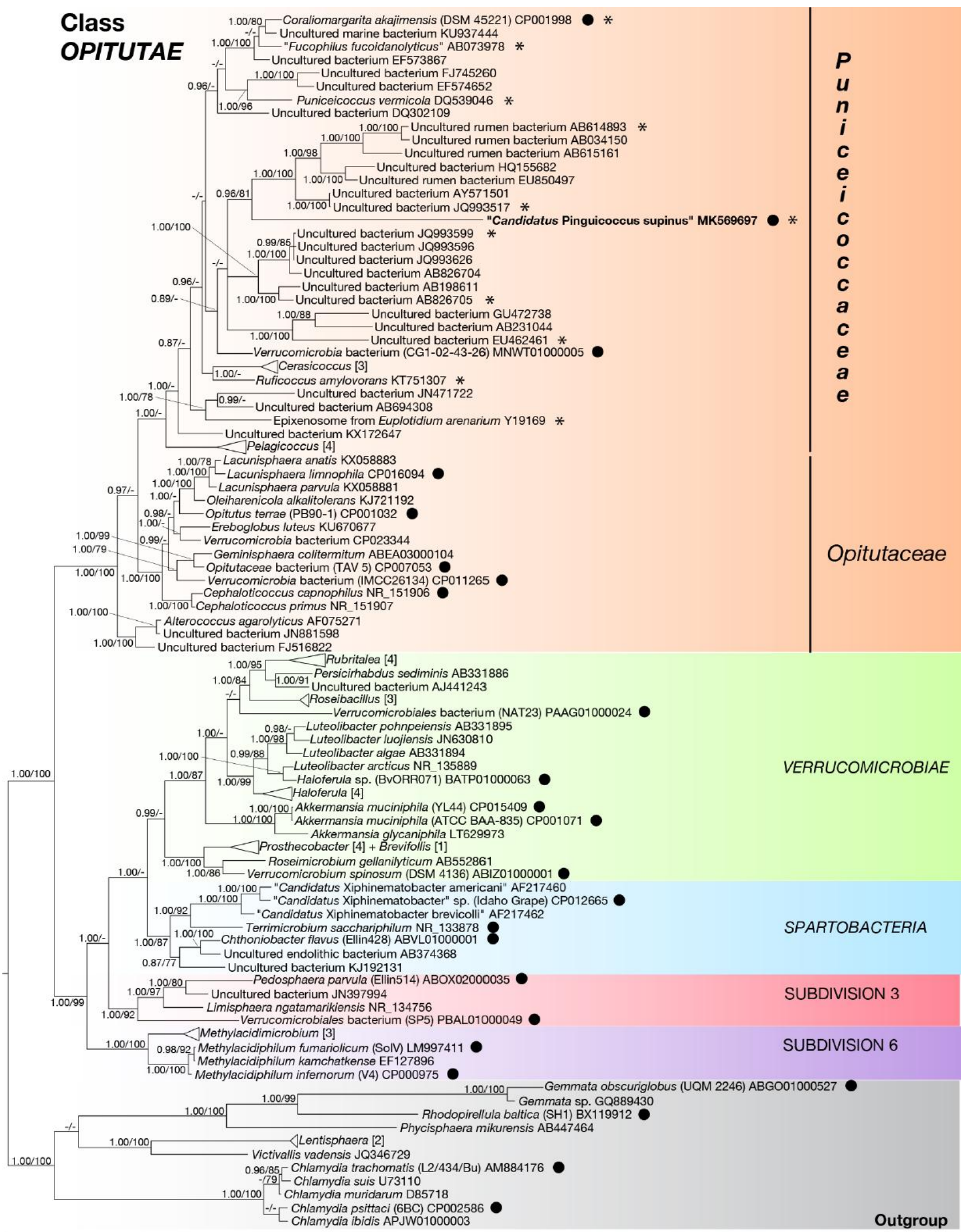


bioRxiv preprint doi: https://doi.org/10.1101/666461; this version posted June 11, 2019. The copyright holder for this preprint (which was not certified by peer review) is the author/funder, who has granted bioRxiv a license to display the preprint in perpetuity. It is made available under aCC-BY-NC-ND 4.0 International license.

\section{Figure 8}

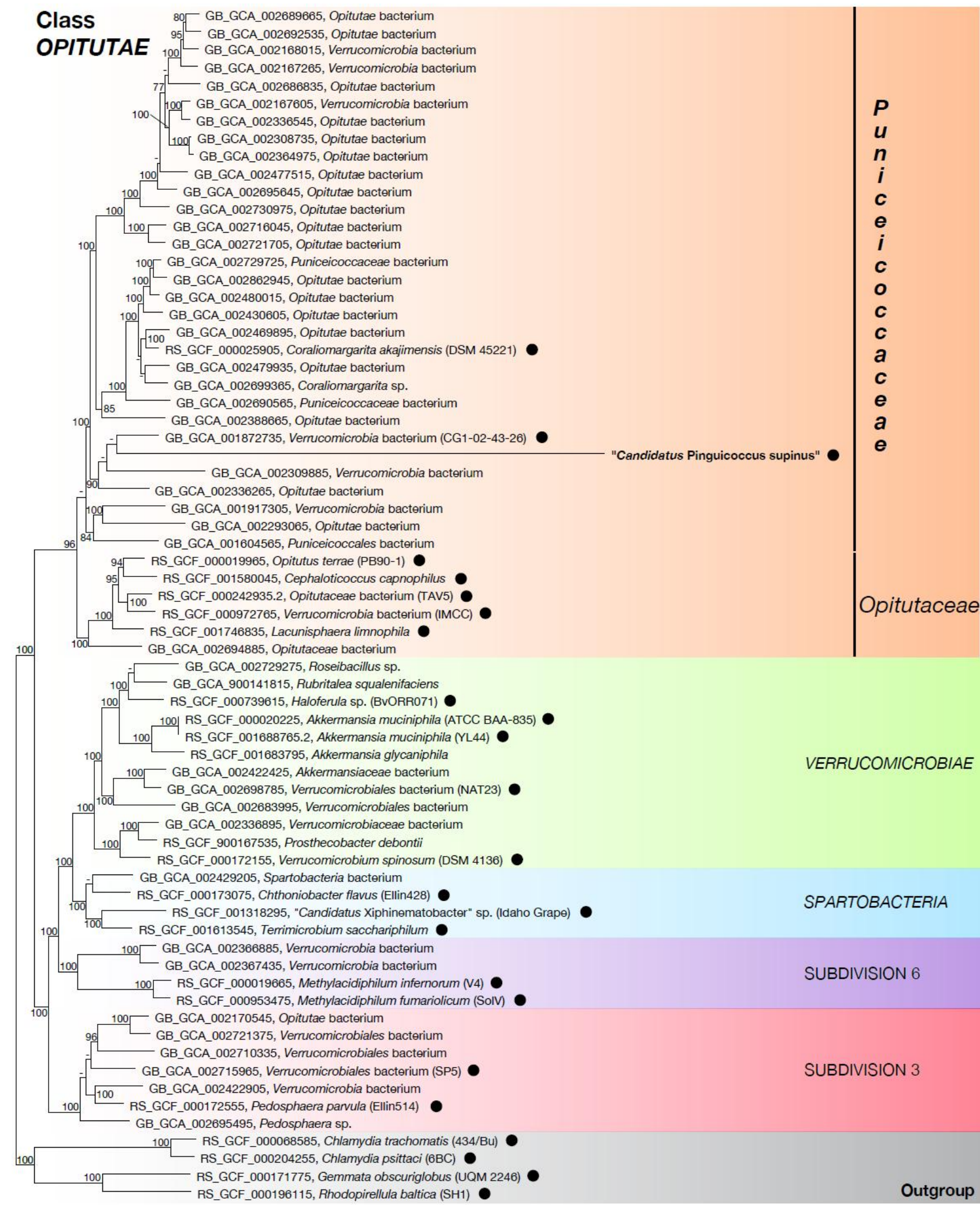


bioRxiv preprint doi: https://doi.org/10.1101/666461; this version posted June 11,2019 . The copyright holder for this preprint (which was not certified by peer review) is the author/funder, who has granted bioRxiv a license to display the preprint in perpetuity. It is made available under aCC-BY-NC-ND 4.0 International license.

\section{Figure 9}

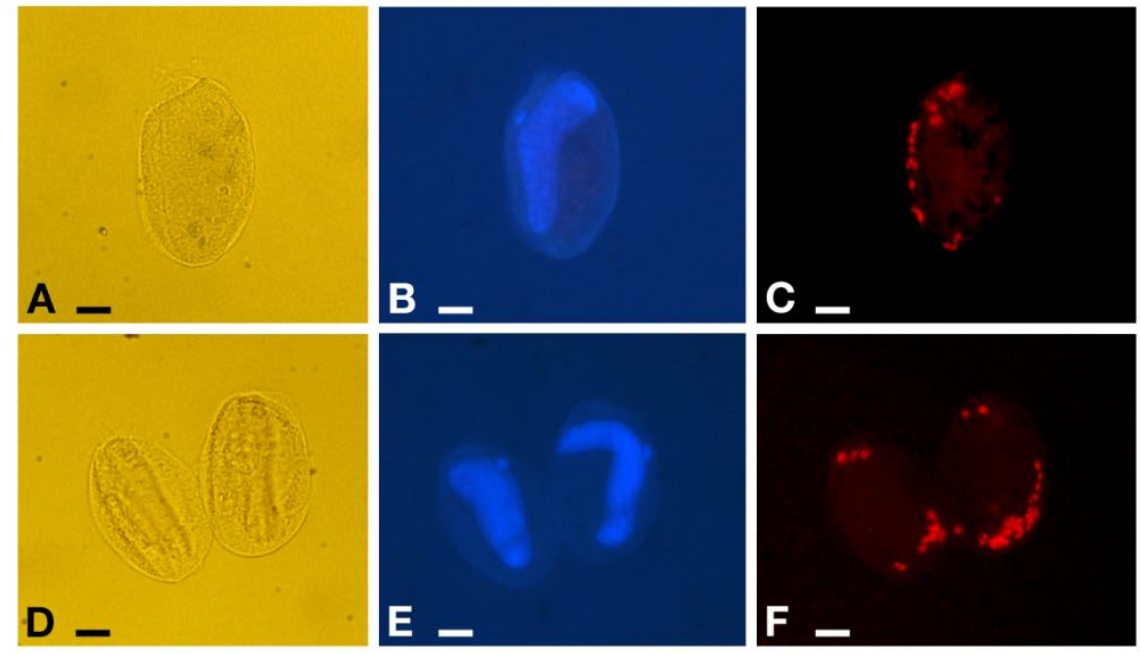


bioRxiv preprint doi: https://doi.org/10.1101/666461; this version posted June 11, 2019. The copyright holder for this preprint (which was not certified by peer review) is the author/funder, who has granted bioRxiv a license to display the preprint in perpetuity. It is made available under aCC-BY-NC-ND 4.0 International license.

Figure 10
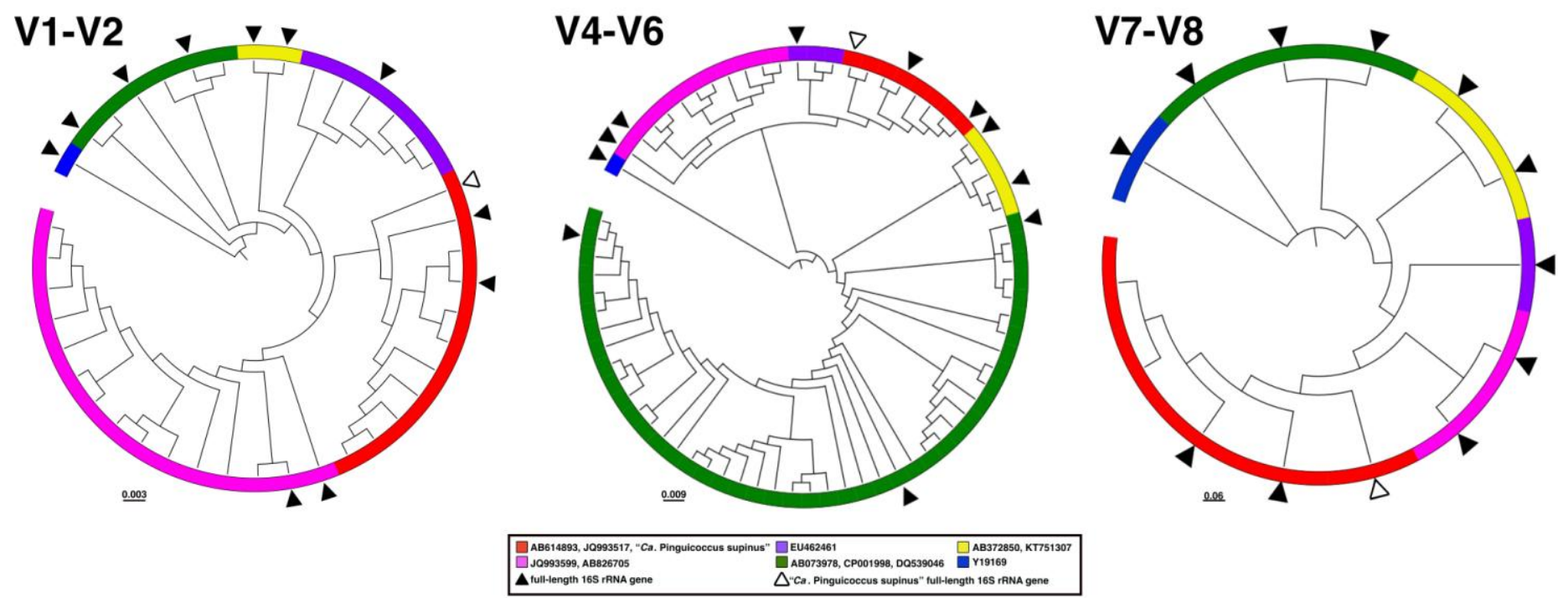